\title{
The role of the Kupferschiefer in the formation of hydrothermal base metal mineralization in the Spessart ore district, Germany Insight from detailed sulfur isotope studies
}

\section{Journal Article}

\section{Author(s):}

Wagner, Thomas; Okrusch, Martin; Weyer, Stefan; Lorenz, Joachim; Lahaye, Yann; Taubald, Heiner; Schmitt, Ralf T.

Publication date:

2010

Permanent link:

https://doi.org/10.3929/ethz-b-000017118

Rights / license:

In Copyright - Non-Commercial Use Permitted

Originally published in:

Mineralium Deposita 45(3), https://doi.org/10.1007/s00126-009-0270-2 


\title{
The role of the Kupferschiefer in the formation of hydrothermal base metal mineralization in the Spessart ore district, Germany: insight from detailed sulfur isotope studies
}

\author{
Thomas Wagner • Martin Okrusch • Stefan Weyer • \\ Joachim Lorenz • Yann Lahaye • Heiner Taubald • \\ Ralf T. Schmitt
}

Received: 8 December 2008 /Accepted: 16 November 2009/Published online: 5 December 2009

(C) Springer-Verlag 2009

\begin{abstract}
The Spessart district (SW Germany), located at the southwestern margin of the Permian Kupferschiefer basin in Central Europe, hosts abundant stratabound and structurally controlled base metal mineralization. The mineralization
\end{abstract}

Editorial handling: A. Boyce

T. Wagner $(\bowtie)$

Institute of Isotope Geochemistry and Mineral Resources, ETH Zurich,

NW F 82.4, Clausiusstrasse 25,

8092 Zürich, Switzerland

e-mail: thomas.wagner@erdw.ethz.ch

M. Okrusch · J. Lorenz

Lehrstuhl für Geodynamik und Geomaterialforschung,

Universität Würzburg,

Am Hubland,

97074 Würzburg, Germany

S. Weyer $\cdot$ Y. Lahaye

Institut für Petrologie, Geochemie und Lagerstättenkunde,

Universität Frankfurt am Main,

Senckenberganlage 28,

60325 Frankfurt am Main, Germany

H. Taubald

Institut für Geowissenschaften, Universität Tübingen,

Wilhelmstr. 56,

72074 Tübingen, Germany

R. T. Schmitt

Museum für Naturkunde,

Leibniz-Institut für Evolutions- und Biodiversitätsforschung,

Humboldt- Universität,

Invalidenstr. 43,

10115 Berlin, Germany styles identified are (1) stratabound $\mathrm{Cu}-\mathrm{Pb}-\mathrm{Zn}-(\mathrm{Ag})$ ores in Zechstein sedimentary rocks, (2) structurally controlled $\mathrm{Cu}-\mathrm{As}-(\mathrm{Ag})$ ores in Zechstein sedimentary rocks, (3) crosscutting $\mathrm{Co}-\mathrm{Ni}-(\mathrm{Bi})-\mathrm{As}$ and $\mathrm{Cu}-\mathrm{Fe}-\mathrm{As}$ veins, (4) stratabound metasomatic $\mathrm{Fe}-\mathrm{Mn}$ carbonate ores in Zechstein dolomite, (5) barren barite veins, and (6) Fe-Mn-As veins in Permian rhyolites. Building on previous work that involved mineralogical, textural, and chemical characterization of the major mineralization types, we have performed a comprehensive sulfur isotope study that applied both conventional and novel laser-ablation multi-collector inductively coupled plasma mass spectrometry techniques. The $\delta^{34} \mathrm{~S}$ values of sulfide minerals from the different ore types are consistently negative and highly variable, in the range between $-44.5 \%$ o and $-3.9 \%$, whereas the $\delta^{34} \mathrm{~S}$ values of barite are all positive in the range between $4.7 \%$ and $18.9 \%$. Remarkably, stratabound and structurally controlled mineralization in Zechstein sedimentary rocks has the least negative $\delta^{34} \mathrm{~S}$ values, whereas vein-type deposits have consistently more negative $\delta^{34} \mathrm{~S}$ values. The observed pattern of sulfide $\delta^{34} \mathrm{~S}$ values can be best interpreted in terms of fluid mixing at the basement-cover interface. Hydrothermal fluids originating from the crystalline basement migrated upward along subvertical fault zones and were periodically injected into groundwaters that were flowing in the post-Variscan sedimentary cover. These groundwaters had interacted with the Zechstein sedimentary rocks, resulting in fluids characterized by elevated concentrations of reduced sulfur (with negative $\delta^{34} \mathrm{~S}$ values) and alkaline $\mathrm{pH}$. Repeated mixing between both chemically contrasting fluids caused rapid and efficient precipitation of sulfide ore minerals in hydrothermal veins with highly variable but distinctly negative $\delta^{34} \mathrm{~S}$ values. 
Keywords Kupferschiefer - Germany · Base metals . Sulfur isotopes $\cdot$ Laser-ablation MC-ICP-MS

\section{Introduction}

Unconformity-related ore deposits constitute a widespread hydrothermal mineralization style that has been recognized in many geological terrains worldwide. They comprise diverse types of metal associations, with prominent examples being the $\mathrm{U}$ deposits of the Athabasca basin in Canada (e.g., Hoewe and Sibbald 1978; Kotzer and Kyser 1995; Kister et al. 2005) and the Cu-Ag-platinum group elements (PGE) deposits of the Permian Kupferschiefer in Central Europe (e.g., Vaughan et al. 1989; Kucha 1990; Speczik 1995; Oszczepalski 1999; Piestrzynski et al. 2002). For many of these deposits, the genetic models are not well established and are subject of an ongoing debate (e.g., Jowett 1986; Cathles et al. 1993; Blundell et al. 2003; Wedepohl and Rentsch 2006).

The formation of base metal deposits related to the Permian Kupferschiefer is of particular interest, because both sedimentary-diagenetic and hydrothermal processes are likely involved in the complex mineralization pattern that is observed throughout the Kupferschiefer basin (Vaughan et al. 1989; Speczik 1995). The Kupferschiefer hosts three different mineralization styles, which are (1) stratabound mineralization of $\mathrm{Cu}$ (and $\mathrm{Ag}$ ) that is present in the reduced part of the stratigraphy (Vaughan et al. 1989; Sawlowicz 1989; Speczik 1995); (2) stratabound mineralization of $\mathrm{Au}$ and PGE that is restricted to the oxidized zone (Piestrzynski and Wodzicki 2000; Bechtel et al. 2002; Piestrzynski et al. 2002); and (3) crosscutting vein-type mineralization of $\mathrm{Cu}, \mathrm{Co}, \mathrm{Ni}, \mathrm{Bi}, \mathrm{Ag}$, and $\mathrm{As}$ (Wagner and Lorenz 2002; Okrusch et al. 2007). Most recent studies have focused on the stratabound mineralization styles, whereas few studies have addressed the role of structurally controlled hydrothermal fluid flow in the formation of Kupferschiefer-hosted base metal mineralization (SchmidtMumm and Wolfgramm 2002, 2004; Wedepohl and Rentsch 2006). A comprehensive study that would integrate observations from spatially associated stratabound and crosscutting vein-type mineralization could thus help to resolve the potential genetic links between these mineralization styles.

The Spessart district, which is located in the southwestern part of the Kupferschiefer basin, hosts both stratabound mineralization that is present in the Zechstein dolomite and the Kupferschiefer, and structurally controlled vein-type mineralization (Fig. 1). The veins are hosted by metamorphic rocks of the crystalline basement and also extend into the overlying Upper Permian sedimentary strata. The fault zones that host base metal mineralization continue as barren barite veins in the Triassic Bunter Sandstone that forms the uppermost part of the stratigraphy. Most studies agree that the vein-type mineralization is of hydrothermal origin (Schmid and Weinelt 1978; Wagner and Lorenz 2002; Okrusch et al. 2007), but their close spatial association with the Kupferschiefer-hosted mineralization points to a possible genetic relationship.

The present study reports the results of a comprehensive sulfur isotope study of both stratabound and vein-type base metal mineralization in the Spessart district. We have performed detailed in situ analysis of a complete suite of sulfide minerals, using a novel laser-ablation multi-collector inductively coupled plasma mass spectrometry (ICP-MS) technique (Bendall et al. 2006). This dataset is combined with conventional sulfur isotope data of barite from both metal-bearing and barren veins that occur in different portions of the stratigraphy (crystalline basement, Zechstein, and Bunter Sandstone). The sulfur isotope data are then integrated with available geological and geochemical information to consider (1) the genetic link between stratabound and vein-type mineralization, (2) the role of sedimentary sulfur in the different hydrothermal mineralization styles, and (3) the likely mechanisms that have resulted in ore deposition.

\section{Geological setting}

The Spessart district is composed of two major geological units (Fig. 1), which are (1) the basement of the Spessart crystalline complex (SCC) and (2) the overlying cover that comprises sedimentary rocks from Lower Permian (Rotliegend) to Triassic (Bunter Sandstone). The SCC constitutes a part of the internal zone of the Central European Variscan orogen (Franke 2000). It consists of NE-trending metamorphosed sedimentary rocks of likely Neoproterozoic, Cambro-Ordovician, and Silurian age with intercalated amphibolites and orthogneisses (Okrusch and Weber 1996). Deformation and metamorphism took place during the Variscan orogeny under medium-pressure, amphibolite-facies conditions (Okrusch and Weber 1996). At the end of the metamorphic cycle, the metamorphic rocks were intruded by an igneous complex composed of quartz diorite, granodiorite, and minor granite. Consistent K-Ar and Ar-Ar dates of minerals from various rock types indicate that uplift and cooling of the SCC took place at 325-315 Ma (Lippolt 1986; Nasir et al. 1991; Dombrowski et al. 1994). During the Permian, several rhyolite bodies were emplaced in the Spessart for which no geochronological data are yet available.

The SCC is unconformably overlain by sedimentary rocks of Permo-Triassic age (Rotliegend, Zechstein, and Bunter Sandstone). Lower Permian (Rotliegend) sedimentary 


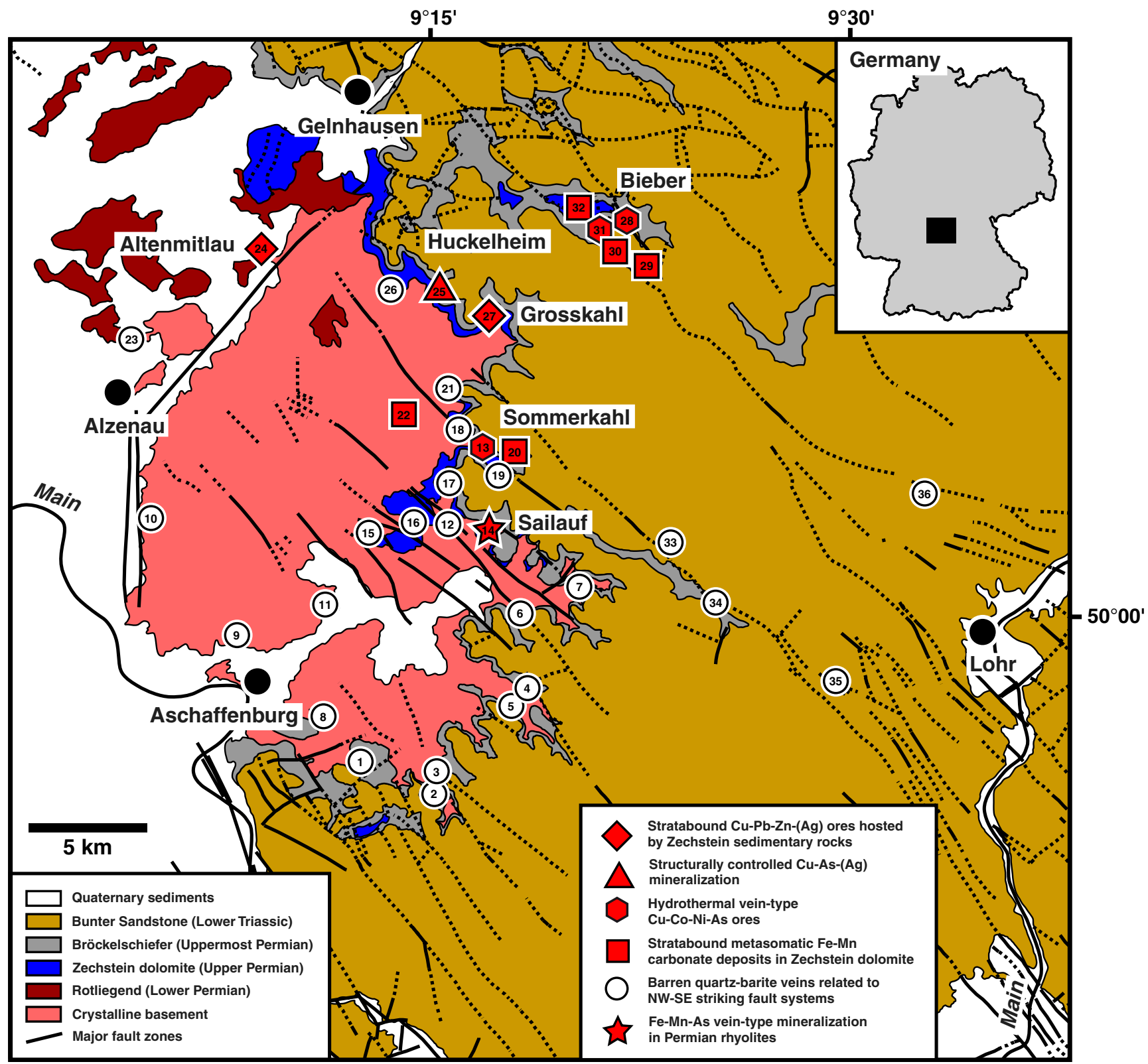

Fig. 1 Geological sketch map of the Spessart district, displaying the distribution of the principal ore mineralization types and the location of the sampled deposits. See Table 1 for key to locality numbers

rocks have a restricted occurrence (Fig. 1) and are overlain by sequences of the uppermost Permian (Zechstein). In the central and northern part of the SCC, they comprise, from bottom to top, (1) a basal breccia and conglomerate unit, (2) the Kupferschiefer, (3) bituminous dolomites of the Werra Cycle, and (4) clay and marlstone sedimentary rocks of the Leine and Aller cycles which contain a well-defined claystone at the top (termed Bröckelschiefer; Paul 1985, 2006; Menning et al. 2005; Kading 2005). Basal breccia, Kupferschiefer, and the Werra Cycle sedimentary rocks were deposited in near-coastal, marginal parts of the Zechstein basin. Compared to the typical organic-rich shales of the Kupferschiefer that were deposited in the deep marine parts of the Zechstein basin under fully euxinic conditions (Bechtel and Püttmann 1997; Kading 2005), the Kupferschiefer of the Spessart district represents a distal facies. This facies is characterized by markedly higher carbonate contents and a coarse lamination, reflecting an alternation of oxidizing and reducing (euxinic) conditions (e.g., Paul 2006; Schumacher et al. 1984).

The sedimentary rocks of the Zechstein are conformably overlain by the Bunter Sandstone (Lower Triassic), which is composed of intercalated beds of sand-rich mudstones, sandstones, and conglomeratic sandstones. Few erosional relicts of lower Middle Triassic limestone are present in the Spessart. The sedimentary rocks of the Middle Triassic to 
Upper Jurassic that have originally covered the entire area were completely eroded during regional uplift.

The Variscan crystalline basement and the sedimentary rocks of the post-Variscan cover are crosscut by two fault systems, which were activated as a consequence of the postVariscan extensional regime in Central Europe (e.g., Ziegler 1987). Both provided important pathways for hydrothermal fluids, manifested by the frequent mineralization with barite (Murawski 1954; Hofmann and Schürenberg 1979). The predominant fault system has a NW-SE strike, and the fault zones dip generally with about $45-80^{\circ}$ towards the SW and NE. A second, less pronounced fault system strikes NE-SW.

\section{Hydrothermal mineralization in the Spessart district}

Six distinct hydrothermal mineralization styles are distinguished (Fig. 2).

1. Stratabound $C u-P b-Z n-(A g)$ mineralization: hosted by the Kupferschiefer and adjacent Zechstein sedimentary rocks (e.g., Zechstein dolomite). Based on bulk rock data (Schmitt 2001), the Kupferschiefer in the Huckelheim-Grosskahl area contains considerable enrichment in $\mathrm{Cu}(2,100-45,000 \mathrm{ppm})$ and minor enrichment in $\mathrm{Zn}(300-3,500 \mathrm{ppm})$ and $\mathrm{Pb}$ (13-145 ppm). Conversely, the Zechstein dolomite contains much lower average $\mathrm{Cu}(90-700 \mathrm{ppm})$ and $\mathrm{Zn}$ (30-840 ppm) grades, but on average higher but variable $\mathrm{Pb}(11-6,350 \mathrm{ppm})$. The very fine-grained primary syngenetic and early to late diagenetic metal

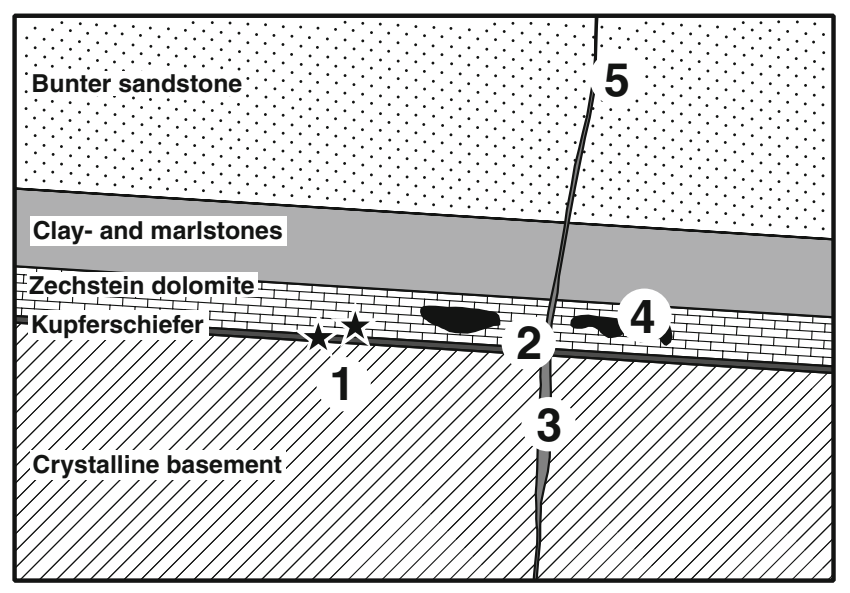

Fig. 2 Schematic cross section illustrating the stratigraphic relationships in the Spessart district and the structural setting of the different ore mineralization types. These are (1) stratabound $\mathrm{Cu}-\mathrm{Pb}-\mathrm{Zn}-(\mathrm{Ag})$ mineralization hosted by sedimentary rocks of the Zechstein, (2) structurally controlled $\mathrm{Cu}-\mathrm{As}-(\mathrm{Ag})$ mineralization related to NE-SW striking faults, (3) $\mathrm{Co}-\mathrm{Ni}-(\mathrm{Bi})-\mathrm{As}$ and $\mathrm{Cu}-\mathrm{Fe}-\mathrm{As}$ vein-type ores, (4) stratabound $\mathrm{Fe}-\mathrm{Mn}$ carbonate ores hosted mainly by Zechstein dolomite, and (5) quartz-barite veins related to NW-SE striking fault systems content was locally extensively remobilized during a subsequent stage of structurally controlled hydrothermal activity. Relicts of the primary mineralization are only locally preserved, e.g., the pyrite-sphalerite-galena mineralization in the lower Zechstein dolomite in the Grosskahl-Huckelheim and Altenmittlau (Fig. 1) areas (Schmitt 2001).

2. $C u-A s-(A g)$ mineralization: occurring as veinlets and impregnations, structurally related to NE-SW striking faults in Zechstein conglomerate, the Kupferschiefer, and the lower part of the Zechstein dolomite (Schmidt et al. 1986; Schmidt and Friedrich 1988; Schmitt 2001). Fault zones arguably acted as major fluid conduits controlling the spatial distribution of the $\mathrm{Cu}-\mathrm{As}-(\mathrm{Ag})$ ores. The ores are dominated by tennantite, enargite, loellingite, and chalcopyrite, with minor siderite, barite, and quartz. The ore assemblages show a distinct variation that appears to be stratigraphically controlled, with typical sulfide assemblages being (1) pyrite-tennantite in the Zechstein conglomerate, (2) pyrite-marcasite-chalcopyrite-enargitetennantite at the base of the Kupferschiefer, and (3) tennantite-loellingite-galena-sphalerite in the upper part of the Kupferschiefer and the overlying Zechstein dolomite. This confirms that the maximum in $\mathrm{Cu}$ grade is generally present at lower stratigraphic levels than the maximum in $\mathrm{Pb}$ (Schmitt 2001).

3. Hydrothermal vein-type $\mathrm{Cu}-\mathrm{Co}-\mathrm{Ni}$-As ores: structurally related to NW-SE striking fault systems. The ore veins represent mineralized parts of major post-Variscan fault zones, which were still active during ore formation, as demonstrated by brecciation and partial mylonitization of parts of the older ore generations. Although the fault zones are continuous from the crystalline basement into the Bunter Sandstone, the ore is restricted to the Zechstein sedimentary rocks and the uppermost part of the basement. Assemblages are variable, the most important subtypes being Ba-Co-Ni veins (Huckelheim; Fig. 1) containing tennantite, skutterudite, nickeline, arsenopyrite, and chalcopyrite (Schmitt 2001); Co-Ni-Bi-As veins (Bieber) containing skutterudite, native bismuth, diarsenides, and sulfarsenides of wide compositional range (Wagner and Lorenz 2002); and $\mathrm{Cu}-\mathrm{Fe}-\mathrm{As}$ veins (Sommerkahl) containing tennantite, enargite, bornite, digenite, pyrite, and chalcopyrite (Okrusch et al. 2007). The main gangue minerals are barite, quartz, and carbonates.

4. Stratabound metasomatic Fe-Mn carbonate deposits: widespread in carbonate-rich portions of the Zechstein sedimentary rocks (Okrusch et al. 2007). The ore textures range from very fine-grained laminated to medium- and coarse-grained, and the ores are dominantly composed of $\mathrm{Mn}$-siderite, with subordinate marcasite, pyrite, loellingite, arsenopyrite, tennantite, 
chalcopyrite, sphalerite, and galena. Rarely, isolated tabular barite crystals up to $5 \mathrm{~mm}$ in size are present in the fine-grained ore types. Although the occurrence of the $\mathrm{Fe}-\mathrm{Mn}$ carbonate ores is stratabound, their association with major fault zones and barite veins suggest a hydrothermal-metasomatic formation (Okrusch et al. 2007).

5. Barren barite veins: found in abundance in the major NW-SE striking post-Variscan fault system that crosscuts both the crystalline basement and the Permo-Triassic sequence (Murawski 1954; Hofmann and Schürenberg 1979; Okrusch et al. 2007). The veins contain minor amounts of quartz, fluorite, carbonates, and sulfide minerals such as chalcopyrite, pyrite, emplectite, tennantite, and arsenopyrite. Larger amounts of sulfides occur only in portions of the barite veins that crosscut the crystalline basement and the Zechstein sedimentary rocks. The abundance of quartz in the barite veins increases with depth.

6. Fe-Mn-As mineralization in rhyolite: very complex hydrothermal veins hosted in Permian rhyolite (Sailauf). The mineralization is characterized by abundant $\mathrm{Fe}$ and Mn oxides, Mn-rich carbonates, native arsenic and bismuth, and barite gangue. This vein system records a complex history of hydrothermal events with radiometrically datable minerals, and the extent and timing of hydrothermal activity is relatively well established (Hautmann et al. 1999; Okrusch et al. 2007). (U-Th)He-dating of a braunite generation that is texturally older than the barite resulted in consistent Middle Jurassic ages around $160 \mathrm{Ma}$, whereas hematite that post-dates the barite gave ages of $145 \mathrm{Ma}$. Several generations of texturally younger hydrothermal celadonite gave K-Ar ages of 120 to $100 \mathrm{Ma}$, pointing to prolonged hydrothermal activity until mid-Cretaceous time.

\section{Samples and methods}

A summary of the sample localities and the mineralization styles is given in Table 1 and mapped in Fig. 1. Representative samples from all mineralization types described above were collected in the field and complemented with selected samples from university collections, notably from the Bieber deposit (Fig. 1). The mineral chemistry and sulfur isotope composition of sulfide minerals were analyzed in situ using standard polished blocks. Unfortunately, Laser-ablation ICP-MS analysis of $\mathrm{Cu}$ sulfides in samples of the syngenetic to early diagenetic $\mathrm{Cu}$ mineralization was not possible due to the small grain sizes. Mineral separates of barite for conventional sulfur isotope analysis were prepared by careful hand-picking under a binocular microscope, followed by cleaning in double-distilled water.

Mineral chemistry

Wavelength-dispersive electron-probe microanalysis of barite was carried out using the CAMECA SX-50 instrument in Würzburg (Germany). Operating conditions were $15 \mathrm{kV}$ acceleration voltage, $15 \mathrm{nA}$ beam current, and a beam diameter of 1-2 $\mu \mathrm{m}$. The following natural and synthetic standards were used for calibration: andradite $(\mathrm{Ca}-\mathrm{K} \alpha)$, $\mathrm{MgO}(\mathrm{Mg}-\mathrm{K} \alpha), \mathrm{SrSO}_{4}(\mathrm{Sr}-\mathrm{L} \alpha)$, and $\mathrm{BaSO}_{4}(\mathrm{Ba}-\mathrm{L} \alpha$, $\mathrm{S}-\mathrm{K} \alpha$ ). The matrix correction was performed by the PAP program (Pouchou and Pichoir 1985) provided by CAMECA. For the given analytical conditions, the detection limit for the elements analyzed is around $0.1 \mathrm{wt} . \%$, and the analytical precision is approximately $1 \%$ for all major elements.

Conventional sulfur isotope analysis

Barite mineral concentrates were analyzed in the stable isotope laboratory in Tübingen, following procedures given in Giesemann et al. (1994). The samples were sealed in tin capsules, converted by an EA-analyzer to $\mathrm{SO}_{2}$ at a reaction temperature of $1,050^{\circ} \mathrm{C}$, and separated at a column temperature of $100^{\circ} \mathrm{C}$. The isotopic composition of $\mathrm{SO}_{2}$ was measured using a Finnigan DeltaXL mass spectrometer. Maximum sample sizes were $0.25 \mathrm{mg}$ of pure $\mathrm{BaSO}_{4}$. The reproducibility of the $\delta^{34} \mathrm{~S}$ measurements was $\pm 0.3 \%$, as monitored by replicate analysis of international standards NBS-123 $\left(\delta^{34} \mathrm{~S}_{\mathrm{V}-\mathrm{CDT}}, 17.1\right)$, IAEA-S-3 $\left(\delta^{34} \mathrm{~S}_{\mathrm{V}-\mathrm{CDT}},-31.0\right)$, and NBS-127 $\left(\delta^{34} \mathrm{~S}_{\mathrm{V}-\mathrm{CDT}}, 20.3\right)$. All sulfur isotope compositions are reported in standard delta notation, relative to Vienna Canon Diablo Troilite (V-CDT).

In situ sulfur isotope analysis with laser-ablation MC-ICP-MS

The in situ sulfur isotope measurements were performed using the Finnigan-Neptune high mass resolution multicollector ICP-MS (Weyer and Schwieters 2003) in Frankfurt, which is equipped with a Merchantek New Wave LUV-213 laser-ablation system. With this technique, the sulfur isotope composition of sulfide minerals can be measured in situ in standard polished sections. The method is described in full detail in Bendall et al. (2006). The isotopes ${ }^{32} \mathrm{~S}$ and ${ }^{34} \mathrm{~S}$ have been measured simultaneously with two separate Faraday collectors. Since all sulfur isotopes are affected by polyatomic mass interferences (when using a plasma source), measurements were performed in the Neptune high-resolution mode which is sufficient to resolve the major mass interferences (e.g., ${ }^{16} \mathrm{O}_{2}$ for ${ }^{32} \mathrm{~S}$, and ${ }^{16} \mathrm{O}^{18} \mathrm{O}$ 
Table 1 Short description of the studied ore deposits and hydrothermal mineralizations, Spessart, Germany

\begin{tabular}{|c|c|c|}
\hline Number & Location & Mineralization style \\
\hline 1 & Quarry, Gailbach & Hematite-bearing calcite-barite vein, in lamprophyre \\
\hline 2 & Stahl quarry, Dörrmorsbach & Quartz- and calcite-bearing barite veins, in quartz diorite \\
\hline 3 & Heinrichsberg mine, Heinrichsberg & Calcite-barite and barite veins, in altered quartz diorite \\
\hline 4 & Hesseltälchen mine, Waldaschaff & Quartz-bearing barite vein, in granodiorite \\
\hline 5 & Pauline mine, Waldaschaff & Barite vein with minor hematite, quartz and sulfides, in granodiorite \\
\hline 6 & Elisabeth mine, Hain & Barite vein with minor hematite and chalcopyrite, in quartz diorite and leucogranite \\
\hline 7 & Simmerwiese mine, Hain & Barite vein, in altered quartz diorite \\
\hline 8 & Wendelberg quarry, Haibach & Barite vein, in orthogneiss (Haibach gneiss unit) \\
\hline 9 & Road cut, Strietwald (Aschaffenburg) & Barite vein, in orthogneiss (Goldbach gneiss unit) \\
\hline 10 & Outcrop, Plattenberg (Dettingen) & Calcite-bearing barite veins, in orthogneiss (Goldbach gneiss unit) \\
\hline 11 & Outcrop, Käsrain (Goldbach) & Barite vein, in orthogneiss (Goldbach gneiss unit) \\
\hline 12 & Marga mine, Eichenberg & Barite veins, with Mn-siderite and quartz in orthogneiss (Goldbach gneiss unit) \\
\hline 13 & Wilhelmine mine, Sommerkahl & $\begin{array}{l}\text { Barite, barite-quartz-ankerite and sulfide veins, in orthogneiss (Schöllkrippen } \\
\text { gneiss unit) }\end{array}$ \\
\hline 14 & Hartkoppe quarry, Sailauf & Barite veins, with carbonates and Mn oxides in rhyolite \\
\hline 15 & Quarry Feldkahler Höhe, Rottenberg & Barite veins, in Zechstein dolomite \\
\hline 16 & Quarry Kalkwerk Hufgard, Rottenberg & Barite veins, dolomite and minor sulfides in Zechstein dolomite \\
\hline 17 & Quarry Kuppe, Eichenberg & Barite vein, in Zechstein dolomite \\
\hline 18 & Outcrop, Sommerkahl & Barite vein, in Zechstein dolomite \\
\hline 19 & Helene mine, Sommerkahl & Fluorite-bearing barite vein, in Zechstein dolomite \\
\hline 20 & Hoffnungsglück mine, Sommerkahl & Quartz-bearing barite veins and metasomatic siderite replacement, in Zechstein dolomite \\
\hline 21 & Unnamed mine, Schöllkrippen & Barite vein, in Zechstein dolomite \\
\hline 22 & Beschert Glück mine, Schöllkrippen & Barite veins, brecciated and cemented with Mn hydroxides, in Zechstein dolomite \\
\hline 23 & Outcrop, Rothenberg (Alzenau) & Barite vein in Zechstein dolomite \\
\hline 24 & Schmitt quarry, Altenmittlau & Galena and tennantite impregnation, in Zechstein dolomite \\
\hline 25 & Segen Gottes mine, Huckelheim & Barite veins, sulfide veins and impregnations, in Zechstein dolomite \\
\hline 26 & Unnamed mine, Huckelheim & Barite vein, in Zechstein dolomite \\
\hline 27 & Hilfe Gottes mine, Grosskahl & Sulfide impregnation, in Zechstein dolomite and Kupferschiefer \\
\hline 28 & Röhriger Kobaltgang, Bieber mine, Bieber & Barite veins and metasomatic Mn-siderite replacement, in Zechstein dolomite \\
\hline 29 & Oberer Maschinenschacht, Bieber mine & Brecciated barite vein with Mn-siderite replacement, in Zechstein dolomite \\
\hline 30 & Open pit, Bieber mine & Mn-siderite replacement and barite vein, in Zechstein dolomite \\
\hline 31 & Erster Lochborner Kobaltschacht, Bieber mine & Barite mineralization with minor quartz and sulfides, in altered gneiss \\
\hline 32 & Quarry, Galgenberg (Bieber) & Barite impregnation, in silicified Zechstein dolomite \\
\hline 33 & Bächlesgrund mine, Heigenbrücken & Barite veins, in Bunter Sandstone \\
\hline 34 & Unnamed mine, Neuhütten & Barite and quartz-barite veins, in Bunter sandstone \\
\hline 35 & Christiane mine, Rechtenbach & Quartz-bearing barite veins, in Bunter sandstone \\
\hline 36 & Katharinenbild mine, Lohr & Barite veins and impregnation, in Bunter sandstone \\
\hline
\end{tabular}

The numbers correspond to those indicated on the map (Fig. 1)

plus ${ }^{16} \mathrm{O}^{16} \mathrm{O}^{1} \mathrm{H}^{1} \mathrm{H}$ for $\left.{ }^{34} \mathrm{~S}\right)$. We used laser parameters of $60 \mu \mathrm{m}$ spot size, $10 \mathrm{~Hz}$ repetition rate, and a laser flux energy of about $2.5 \mathrm{~J} / \mathrm{cm}^{2}$ which was sufficient to produce a signal of above $10 \mathrm{~V}\left(10^{-10} \mathrm{~A}\right)$ for ${ }^{32} \mathrm{~S}$ for most sulfide minerals. We achieved an internal precision of better than $0.1 \%$ ( 1 standard error) for most measurements with this setup.

The samples were measured relative to an internal standard (a large unzoned pyrite crystal from a metamorphosed massive sulfide deposit, Kambalda, Western Australia) with typically two standard measurements followed by three to six sample measurements on one sample, followed again by two standard measurements. The internal standard was calibrated against the international standard V-CDT (Bendall et al. 2006). We used this calibration to recalculate the measured sulfur isotope composition into standard delta notation relative to the V-CDT scale. We analyzed two to three spots for most mineral grains, and the uncertainty in $\delta^{34} \mathrm{~S}$ was expressed by the precision (2SE) of the replicate analyses on 
a grain. However, for about $30 \%$ of the grains, the variation of replicate measurements is above $1.5 \%$ and thus exceeds significantly the reproducibility of the bracketing standard measurements (typically about $0.5-1.0 \%$ ). This implies isotopic heterogeneity on the grain scale (see below), and the precision given in Tables 2, 3, 4, and 5 is a measure for the heterogeneity of the mineral rather than the analytical precision in such cases. Occasionally, we could not perform replicate analyses on a single grain (e.g., because the grain was too small). In such cases, we expressed the uncertainty of the individual sample measurements by using the reproducibility (2 SD) of the standard measurements before and after the respective sample measurements. Sulfur isotope analyses on galena yielded mostly unsatisfactory results, which is likely due to some unresolved matrix effect.

\section{Mineralogy and textures}

\section{Stratabound $\mathrm{Cu}-\mathrm{Pb}-\mathrm{Zn}-(\mathrm{Ag})$ mineralization}

The first, presumably syngenetic, sulfides in the Zechstein conglomerate, the Kupferschiefer, and the lower part of the Zechstein dolomite in the Huckelheim-Grosskahl area (Fig. 1) are spheroidal to oval pyrite framboids, $10-30 \mu \mathrm{m}$ in diameter, consisting of very small euhedral crystals. Distinctly larger (up to $10 \mu \mathrm{m}$ ) euhedral crystals of pyrite occur either as isolated grains or in spheroidal aggregates and formed via recrystallization of the pyrite framboids (Schmitt 2001; cf. Sawlowicz 1990). The Zechstein conglomerate and the lower part of the Kupferschiefer (but not the Zechstein dolomite) contain two types of pyrite, which are (1) aggregates of anhedral pyrite that are irregularly intergrown with dolomite and marcasite, and (2) isolated euhedral pyrite crystals. In the lower Zechstein dolomite (Altenmittlau and Grosskahl), anhedral galena commonly fills cavities between euhedral dolomite crystals. In different samples of the same horizon, anhedral tennantite is the dominant ore mineral, impregnating a strongly brecciated dolomite. Tennantite contains rare inclusions of framboidal pyrite, loellingite, and chalcopyrite.

Table 2 Sulfur isotope data of stratabound mineralization (type 1) in sedimentary rocks of the Zechstein dolomite

\begin{tabular}{cccccc}
\hline Sample & Locality & Mineral & Spots & $\delta^{34} \mathrm{~S}_{\mathrm{V}-\mathrm{CDT}}(\%)$ & $2 \mathrm{SE}$ \\
\hline \multicolumn{5}{c}{ Stratabound } \\
Alt3-4 & 24 & Galena & 6 & -15.9 & 1.1 \\
Alt3-6 & 24 & Tennantite & 2 & -20.3 & 1.4 \\
Gro1-41 & 27 & Galena & 2 & -4.4 & 0.7
\end{tabular}

All samples were analyzed in situ using laser-ablation multi-collector inductively coupled plasma mass spectrometry
Cu-As-(Ag) mineralization

The ore-bearing Zechstein strata in the HuckelheimGrosskahl area contain abundant structurally controlled $\mathrm{Cu}-\mathrm{Fe}-\mathrm{As}$ mineralization that is dominated by chalcopyritetennantite assemblages. Chalcopyrite is commonly present as small (few micrometers) anhedral inclusions in tennantite, whereas coarse-grained chalcopyrite aggregates are restricted to the base of the Kupferschiefer. This coarse-grained chalcopyrite contains inclusions of pyrite, tennantite, enargite, dolomite, and siderite (Fig. 3). Microfractures in chalcopyrite are filled with younger enargite and tennantite, pyrite, or marcasite (Fig. 3c). Tennantite is the dominant sulfide mineral in all ore-bearing horizons of the Zechstein sedimentary rocks and exhibits considerable textural diversity. In the Zechstein conglomerate, tennantite is present as anhedral aggregates, which essentially replace the cement of the conglomerate. Within the Zechstein conglomerate and at the base of the Kupferschiefer, complex intergrowths of tennantite with chalcopyrite surround texturally older pyrite and gangue minerals. In the upper part of the Kupferschiefer and the lower part of the Zechstein dolomite, tennantite forms anhedral to subhedral aggregates, which contain abundant inclusions of dolomite and loellingite and rare inclusions of sphalerite and galena. In the lower part of the Zechstein dolomite, galena is more abundant.

\section{Hydrothermal vein-type $\mathrm{Cu}-\mathrm{Co}-\mathrm{Ni}$-As ores}

The $\mathrm{Cu}$-Fe-As veins of the Wilhelmine deposit (Sommerkahl; Fig. 1) are dominated by tennantite, which is associated with pyrite and chalcopyrite. Samples from the eastern part of the deposit contain considerable bornite, associated with digenite and enargite. By contrast, bornite and digenite are absent in the western part of the deposit. Three different mineralization stages can be distinguished (Okrusch et al. 2007), which are (1) the early stage, (2) the recrystallization stage, and (3) the late alteration stage. Most gangue minerals in the vein assemblage, including quartz and carbonates, formed at the onset of the early stage, prior to the majority of the sulfide ore minerals. The sulfide assemblage of this stage is characterized by widespread relicts of colloform textures. Spherical aggregates are common (Fig. 4) and are composed of alternating zones of pyrite, tennantite, bornite, digenite, chalcopyrite, enargite, and quartz (Fig. 4a). During the recrystallization stage, the colloform textures were overgrown by second generations of bornite, digenite, enargite, tennantite, pyrite and, more rarely, also chalcopyrite (Fig. 4). Large grains of this bornite show abundant exsolution lamellae of chalcopyrite (Fig. 4c, d). Second-generation bornite, chalcopyrite, and enargite are partly replaced by tennantite and digenite. During the late alteration stage, the older $\mathrm{Cu}$ sulfide minerals were replaced along grain 
Table 3 Sulfur isotope data of structurally controlled mineralization (type 2) in sedimentary rocks of the Upper Permian (Zechstein)

\begin{tabular}{|c|c|c|c|c|c|}
\hline Sample & Locality & Mineral & Spots & $\delta^{34} \mathrm{~S}_{\mathrm{V}-\mathrm{CDT}}(\%)$ & $2 \mathrm{SE}$ \\
\hline \multicolumn{6}{|c|}{ Structurally controlled mineralization in Zechstein conglomerate $(n=3)$} \\
\hline \multirow[t]{2}{*}{ Huc2-3 } & 25 & Tennantite & 3 & -8.8 & 0.8 \\
\hline & & Pyrite & 3 & -5.8 & 0.8 \\
\hline \multicolumn{6}{|c|}{ Structurally controlled mineralization in Kupferschiefer $(n=16)$} \\
\hline \multirow[t]{5}{*}{ Huc1-1 } & 25 & Tennantite & 2 & -6.0 & 0.8 \\
\hline & & Tennantite & 1 & -6.0 & 0.6 \\
\hline & & Chalcopyrite & 2 & -7.2 & 0.3 \\
\hline & & Chalcopyrite & 2 & -7.9 & 1.1 \\
\hline & & Pyrite & 2 & -3.9 & 1.9 \\
\hline \multirow[t]{4}{*}{ Huc1-3 } & 25 & Tennantite & 2 & -4.1 & 1.1 \\
\hline & & Enargite & 1 & -4.2 & 0.6 \\
\hline & & Chalcopyrite & 2 & -9.0 & 1.4 \\
\hline & & Chalcopyrite & 2 & -7.1 & 0.6 \\
\hline \multirow[t]{2}{*}{ Huc2-9 } & 25 & Tennantite & 1 & -11.4 & 0.6 \\
\hline & & Tennantite & 3 & -7.7 & 3.0 \\
\hline Gro1-8 & 27 & Tennantite & 1 & -11.8 & 0.9 \\
\hline \multirow[t]{4}{*}{ Gro1-19 } & 27 & Chalcopyrite & 2 & -9.7 & 0.4 \\
\hline & & Chalcopyrite & 3 & -10.3 & 0.6 \\
\hline & & Enargite & 2 & -7.1 & 0.4 \\
\hline & & Pyrite & 1 & -9.8 & 0.9 \\
\hline \multicolumn{6}{|c|}{ Structurally controlled mineralization in Zechstein dolomite $(n=4)$} \\
\hline Huc2-11 & 25 & Tennantite & 2 & -8.1 & 0.3 \\
\hline \multirow[t]{3}{*}{ Huc2-24 } & 25 & Tennantite & 3 & -9.1 & 0.1 \\
\hline & & Tennantite & 2 & -8.6 & 3.7 \\
\hline & & Tennantite & 2 & -6.4 & 0.1 \\
\hline
\end{tabular}

All samples were analyzed in situ using laser-ablation multi-collector inductively coupled plasma mass spectrometry

boundaries and microfractures by the blue-remaining covellite phases yarrowite and spionkopite, whereas covellite proper is rare (Fig. 4b). The late barite that is present in part of the samples was also formed during this stage.

In the Co-Ni-Bi veins of the Bieber deposit, three sequential stages of ore formation can be distinguished, which are (1) the early $\mathrm{Cu}$ stage, (2) the main $\mathrm{Co}-\mathrm{Ni}-\mathrm{Bi}$ stage, and (3) the late stage (Wagner and Lorenz 2002). The $\mathrm{Cu}$ stage commences with the formation of quartz and tabular barite, which are overgrown by chalcopyrite and tennantite. Tennantite is present as massive aggregates (Fig. 5) and contains anhedral to subhedral inclusions of pyrite (Fig. 5a), chalcopyrite (Fig. 5b), marcasite, galena, and sphalerite. Close to fault zones, tennantite has been brecciated, the microfractures being filled with small, hopper-shaped crystals of an early generation of skutterudite. The Co-Ni-Bi stage commences with the formation of native bismuth, followed by nickeline and maucherite. The main generation of skutterudite is present either as euhedral crystals or dendritic to massive aggregates. Subsequently, complex diarsenide and sulfarsenide rosettes composed of rammelsbergite/pararammelsbergite, gersdorffite, safflorite, and loellingite formed. Barite was formed simultaneously with skutterudite, whereas the majority of siderite crystallized close to the termination of the Co-Ni-Bi stage. During the late stage, which occurred after a major brecciation event, new generations of barite, skutterudite, and native bismuth, along with alloclasite, emplectite, and bismuthinite, were deposited. Coarse-grained emplectite encloses brecciated safflorite (Fig. 5c), and late fractures in brecciated tennantite are filled by barite and marcasite (Fig. 5d).

Stratabound metasomatic Fe-Mn carbonate deposits

The hydrothermal-metasomatic Mn-siderite ores contain sulfide minerals, which show textural similarities to the structurally controlled mineralization in the Zechstein sedimentary rocks. Most sulfide-rich samples contain coarse-grained (up to $1 \mathrm{~mm}$ ) tennantite, which is commonly rimmed by chalcopyrite. More rarely, euhedral rhombshaped arsenopyrite or loellingite crystals have grown at the 
Table 4 Sulfur isotope data of hydrothermal vein-type sulfide mineralization (type 3), Spessart, Germany

\begin{tabular}{|c|c|c|c|c|c|}
\hline Sample & Locality & Mineral & Spots & $\delta^{34} \mathrm{~S}_{\mathrm{V-CDT}}(\% \mathrm{)})$ & $2 \mathrm{SE}$ \\
\hline \multicolumn{6}{|c|}{ Vein-type mineralization $(n=64)$} \\
\hline \multirow[t]{2}{*}{ W23-83 } & 13 & Tennantite & 3 & -30.3 & 1.1 \\
\hline & & Bornite & 2 & -31.5 & 0.6 \\
\hline \multirow[t]{2}{*}{ W23-84 } & 13 & Tennantite & 2 & -27.9 & 0.6 \\
\hline & & Pyrite & 1 & -34.2 & 0.7 \\
\hline \multirow[t]{3}{*}{ W23-85 } & 13 & Tennantite & 3 & -26.9 & 0.9 \\
\hline & & Bornite & 2 & -29.9 & 1.5 \\
\hline & & Pyrite & 2 & -35.5 & 0.8 \\
\hline \multirow[t]{4}{*}{ W23-86 } & 13 & Tennantite & 2 & -34.0 & 2.4 \\
\hline & & Tennantite & 2 & -35.2 & 1.9 \\
\hline & & Pyrite & 2 & -44.5 & 0.6 \\
\hline & & Pyrite & 2 & -40.2 & 0.6 \\
\hline \multirow[t]{8}{*}{ W23-87 } & 13 & Tennantite & 2 & -29.6 & 1.3 \\
\hline & & Bornite & 2 & -30.4 & 0.5 \\
\hline & & Bornite & 2 & -25.9 & 1.7 \\
\hline & & Bornite & 1 & -22.7 & 1.0 \\
\hline & & Digenite & 2 & -31.3 & 0.4 \\
\hline & & Digenite & 3 & -24.4 & 1.3 \\
\hline & & Pyrite & 1 & -29.7 & 0.5 \\
\hline & & Pyrite & 1 & -27.4 & 1.3 \\
\hline W23-88 & 13 & Tennantite & 3 & -31.4 & 1.9 \\
\hline \multirow[t]{7}{*}{ W23-89a } & 13 & Tennantite & 2 & -24.5 & 1.3 \\
\hline & & Bornite & 2 & -20.1 & 0.5 \\
\hline & & Digenite & 2 & -20.7 & 1.0 \\
\hline & & Enargite & 2 & -20.0 & 0.1 \\
\hline & & Pyrite & 3 & -32.2 & 3.4 \\
\hline & & Pyrite & 2 & -29.7 & 1.0 \\
\hline & & Pyrite & 2 & -27.8 & 2.7 \\
\hline \multirow[t]{2}{*}{ W23-89b } & 13 & Tennantite & 3 & -16.1 & 0.5 \\
\hline & & Enargite & 2 & -15.0 & 0.6 \\
\hline \multirow[t]{6}{*}{ W23-90 } & 13 & Tennantite & 2 & -30.0 & 0.6 \\
\hline & & Tennatite & 2 & -29.9 & 0.9 \\
\hline & & Digenite & 2 & -29.8 & 1.6 \\
\hline & & Enargite & 2 & -28.8 & 0.9 \\
\hline & & Pyrite & 2 & -40.2 & 1.5 \\
\hline & & Pyrite & 1 & -31.1 & 0.6 \\
\hline \multirow[t]{5}{*}{ W23-91 } & 13 & Tennantite & 2 & -29.4 & 2.4 \\
\hline & & Bornite & 2 & -28.2 & 0.1 \\
\hline & & Bornite & 2 & -28.2 & 0.0 \\
\hline & & Pyrite & 2 & -27.6 & 2.1 \\
\hline & & Yarrowite & 2 & -43.8 & 0.0 \\
\hline \multirow[t]{2}{*}{ W23-115 } & 13 & Tennantite & 2 & -21.9 & 0.9 \\
\hline & & Bornite & 3 & -23.9 & 0.6 \\
\hline WW-1a & 13 & Chalcopyrite & 2 & -12.8 & 0.6 \\
\hline Huc1-2 & 25 & Tennantite & 4 & -7.5 & 0.9 \\
\hline Huc1-4 & 25 & Tennantite & 4 & -7.8 & 2.7 \\
\hline Bie124 & 28 & Emplectite & 3 & -22.1 & 0.8 \\
\hline \multirow[t]{2}{*}{ Bie149 } & 28 & Tennantite & 2 & -24.0 & 6.2 \\
\hline & & Tennantite & 2 & -18.9 & 0.2 \\
\hline
\end{tabular}


Table 4 (continued)

\begin{tabular}{|c|c|c|c|c|c|}
\hline Sample & Locality & Mineral & Spots & $\delta^{34} \mathrm{~S}_{\mathrm{V}-\mathrm{CDT}}(\%)$ & $2 \mathrm{SE}$ \\
\hline & & Tennantite & 2 & -28.4 & 2.3 \\
\hline & & Chalcopyrite & 2 & -28.3 & 0.1 \\
\hline & & Pyrite & 3 & -33.4 & 0.1 \\
\hline & & Pyrite & 3 & -29.0 & 4.9 \\
\hline & & Chalcoyrite & 2 & -29.7 & 2.2 \\
\hline \multirow[t]{2}{*}{ Bie151a } & 28 & Emplectite & 3 & -27.2 & 0.9 \\
\hline & & Emplectite & 3 & -22.0 & 2.9 \\
\hline Bie243 & 28 & Gersdorffite & 3 & -5.7 & 0.2 \\
\hline \multirow[t]{4}{*}{$\mathrm{Bie} 452 \mathrm{a}$} & 28 & Tennantite & 3 & -17.4 & 3.6 \\
\hline & & Tennantite & 3 & -19.4 & 1.4 \\
\hline & & Marcasite & 2 & -24.9 & 3.2 \\
\hline & & Marcasite & 2 & -24.7 & 5.8 \\
\hline \multirow[t]{4}{*}{ JL263-204 } & 31 & Tennantite & 2 & -21.5 & 1.8 \\
\hline & & Tennantite & 3 & -21.8 & 0.8 \\
\hline & & Tennantite & 3 & -22.9 & 1.4 \\
\hline & & Chalcopyrite & 3 & -22.8 & 0.9 \\
\hline
\end{tabular}

The data were obtained using laser-ablation multi-collector inductively coupled plasma mass spectrometry analysis

margins of tennantite, sometimes partly replacing the tennantite (Fig. 6). Both arsenopyrite and loellingite can also be present as isolated crystals at the grain boundaries of the Mn-siderite (Fig. 6a). In places, isolated anhedral aggregates of marcasite or sphalerite occur within the Mn-siderite, texturally not in contact with the tennantite.

\section{Barren barite veins}

Barite veins with small amounts of quartz and sulfides are abundant in the entire Spessart area. Although they are texturally variable, their mineral assemblages are generally rather uniform. The barite veins in the crystalline basement and Bunter Sandstone commonly show an early generation of euhedral quartz, which is associated with minor amounts of sulfides (chalcopyrite, pyrite, and rare tennantite). Barite veins in the Zechstein dolomite contain an early generation of carbonates (calcite and dolomite), whereas quartz is generally absent. The early vein assemblages are overgrown by large amounts of the main barite generation, which is present as tabular to granular masses (Fig. 6b). The center of the veins contains a second generation of barite that forms euhedral translucent crystals, which are associated with quartz, carbonates (calcite, dolomite, or ankerite), and rare fluorite. Many barite veins host small amounts of sulfides, which are commonly present as inclusions within the massive barite. Chalcopyrite and pyrite are the most abundant sulfides, whereas acicular crystals of emplectite are less common. Rarely, the barite veins do also host some tennantite or enargite, which are always associated with chalcopyrite.

\section{Sulfur isotope data}

The sulfur isotope composition of sulfide minerals from 42 samples (originating from 11 different localities) was determined in situ using a novel laser-ablation multicollector ICP-MS technique. The results from the diverse mineralization types hosted by Zechstein sedimentary rocks and vein-type mineralization are summarized in Tables 2, 3, 4 , and 5. Selected data points within their textural context are shown in Figs. 3, 4, 5, and 6. All sulfide minerals from the different mineralization types display consistently negative $\delta^{34} \mathrm{~S}$ values and considerable isotopic variability (Fig. 7). Sulfides from base metal mineralization that is hosted by Zechstein sedimentary rocks have all moderately negative $\delta^{34} \mathrm{~S}$ values. Sulfides from stratabound mineralization in the Zechstein dolomite (type 1) have $\delta^{34} \mathrm{~S}$ values in the range between $-20.3 \%$ and $-4.4 \%$ (Table 2), whereas sulfides from structurally controlled mineralization (type 2) in the Zechstein sedimentary rocks have $\delta^{34} \mathrm{~S}$ values in a comparatively narrow range between $-11.8 \%$ o and $-3.9 \%$ (Table 3). Sulfides from the different stratigraphic units studied (Zechstein conglomerate, Kupferschiefer, and Zechstein dolomite) display rather similar sulfur isotope data, with $\delta^{34} \mathrm{~S}$ values being in the range of $-11.8 \%$ to $-3.9 \%$.

The $\delta^{34} \mathrm{~S}$ values of sulfide minerals (tennantite, enargite, bornite, digenite, chalcopyrite, and pyrite) from the Wilhelmine vein-type deposit (type 3 ) are the most negative ones in the entire dataset and range between $-44.5 \%$ and $-12.8 \%$ o (Table 4), thus confirming earlier results from a limited number of samples (Okrusch et al. 2007). Similarly, negative 
Table 5 Sulfur isotope data of sulfide mineralization in metasomatic Mn-siderite (type 4)

\begin{tabular}{|c|c|c|c|c|c|}
\hline Sample & Locality & Mineral & Spots & $\delta^{34} \mathrm{~S}_{\mathrm{V}-\mathrm{CDT}}(\%)$ & $2 \mathrm{SE}$ \\
\hline \multicolumn{6}{|c|}{ Sulfide mineralization in metasomatic Mn-siderite $(n=5)$} \\
\hline \multirow[t]{3}{*}{ JL174-35 } & 29 & Marcasite & 1 & -11.6 & 0.4 \\
\hline & & Marcasite (core) & 2 & 10.8 & 3.7 \\
\hline & & Marcasite (rim) & 4 & -27.8 & 5.8 \\
\hline Sp06-84 & 29 & Tennantite & 2 & -13.4 & 0.6 \\
\hline JL295-19 & 30 & Sphalerite & 2 & -13.2 & 0.5 \\
\hline
\end{tabular}

All samples were analyzed in situ using laser-ablation multi-collector inductively coupled plasma mass spectrometry

values in the range between $-33.4 \%$ and $-17.4 \%$ were found for the sulfides (tennantite, emplectite, chalcopyrite, and pyrite) from the Co-Ni-Bi-As veins of the Bieber deposit (Table 4). By contrast, a single analysis of gersdorffite gave a substantially less negative $\delta^{34} \mathrm{~S}$ value of $-5.7 \%$. Tennantite and sphalerite from metasomatic Mn-siderite ore (type 4) have also moderately negative and homogeneous $\delta^{34} \mathrm{~S}$ in the range between $-13.4 \%$ and $-11.6 \%$ (Table 5). However, one of the marcasite aggregates (sample JL174-35) displays isotopic some heterogeneity with positive $\delta^{34} \mathrm{~S}$ values
Fig. 3 Photomicrographs in reflected light showing representative textures of stratabound (type 2) and structurally controlled (type 3) mineralization in Zechstein sedimentary rocks, with superposed $\delta^{34} \mathrm{~S}$ values (\%). a Anhedral aggregates of pyrite $(p y)$ enclosed in tennantite (ten), intergrown with chalcopyrite $(c p)$. Lower part of the Kupferschiefer, Segen Gottes mine (Huckelheim). Sample: Huc1-1. Width of field: $900 \mu \mathrm{m}$. b Tennantite intergrown with chalcopyrite and pyrite. Lower part of the Kupferschiefer, Segen Gottes mine (Huckelheim). Sample: Huc1-1. Width of field: $1.25 \mathrm{~mm}$. c Coarse-grained chalcopyrite with veinlets of enargite $(e n)$ or marcasite $(m c)$, the latter being partly altered to yarrowite/spionkopite. Lower part of the Kupferschiefer, Segen Gottes mine (Huckelheim).

Sample: Huc1-3. Width of field: $1.2 \mathrm{~mm}$. d Pyrite crystals enclosed in chalcopyrite. Lower part of the Kupferschiefer, Hilfe Gottes mine (Grosskahl). Sample: Gro1-19. Width of field: $1.25 \mathrm{~mm}$. e Coarse-grained chalcopyrite with veinlets of enargite. Lower part of the Kupferschiefer, Hilfe Gottes mine (Grosskahl). Sample: Gro1-19. Width of field: $1.25 \mathrm{~mm}$
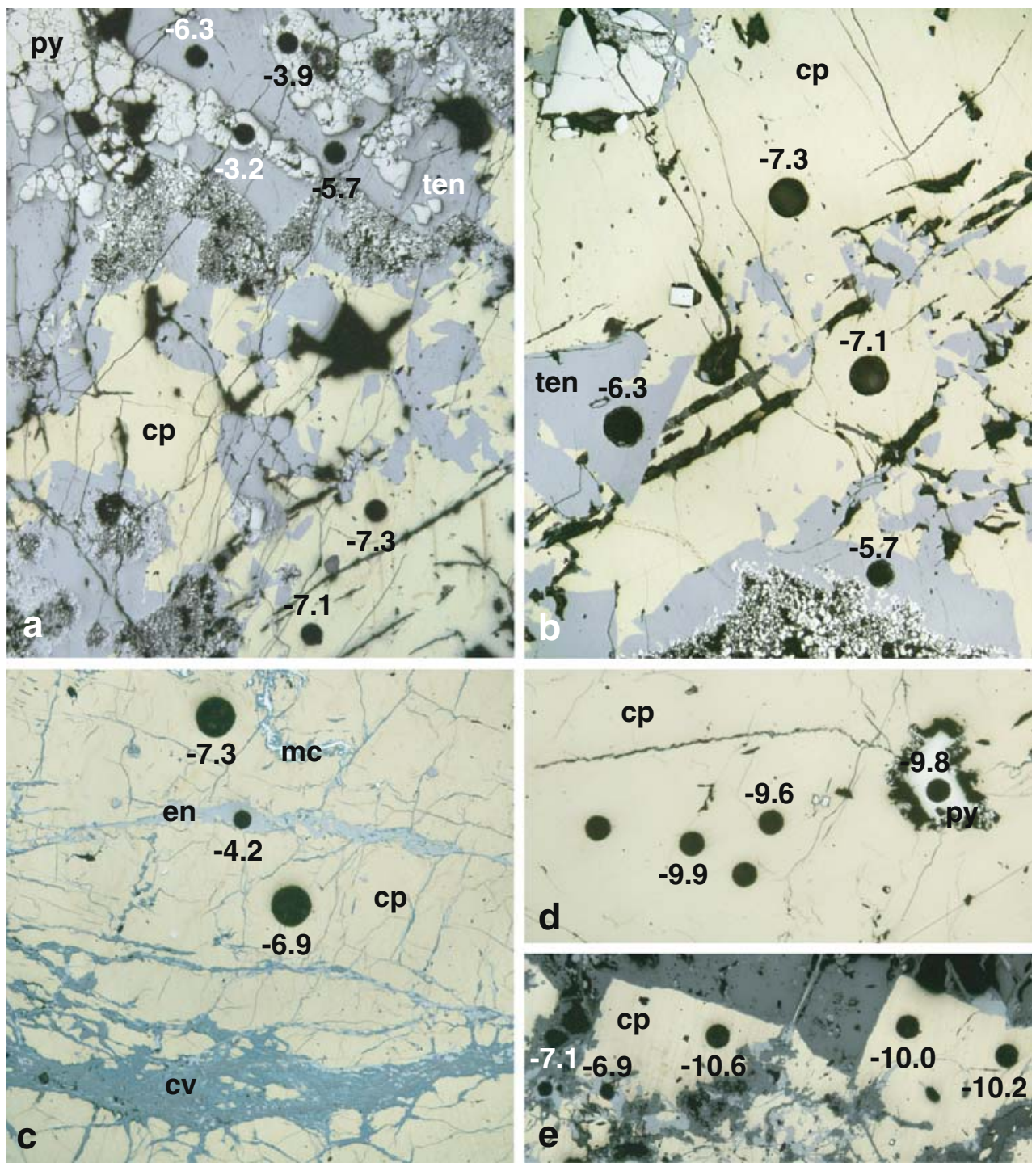
Fig. 4 Photomicrographs in reflected light showing representative textures of vein-type ore mineralization (type 3 ), Wilhelmine deposit, with superposed $\delta^{34} \mathrm{~S}$ values (\%). a Complex intergrowth of pyrite $(p y)$, chalcopyrite $(c p)$, bornite $(b n)$, enargite (en), and digenite $(d g)$, overgrown by secondgeneration bornite $(b n 2)$. Later enargite (en2) fills a crack in recrystallized pyrite that clearly derived from colloform pyrite. Sample: W23-89a. Width of field: $1.25 \mathrm{~mm}$. b Intergrowth of bornite and tennantite (ten), crosscut by a veinlet that is filled with the blue-remaining covellite phases $(c v)$ yarrowite and spionkopite and rare covellite proper. Sample: W23-91. Width of field: $1.7 \mathrm{~mm}$. c Cockade-shaped aggregates of pyrite, intergrown with late generations of bornite $(b n 2)$ and digenite $(d g 2)$, with few exsolution lamellae of chalcopyrite. Sample: W23-87. Width of field: $950 \mu \mathrm{m}$. d Anhedral fine-grained pyrite, enclosed by late generations of bornite $(b n 2)$ and digenite (dg2). Sample: W23-87. Width of field: $950 \mu \mathrm{m}$. e Vein filling, composed of symmetric pyrite bands that are overgrown by tennantite. Sample: W23-86. Width of field: $1.2 \mathrm{~mm}$
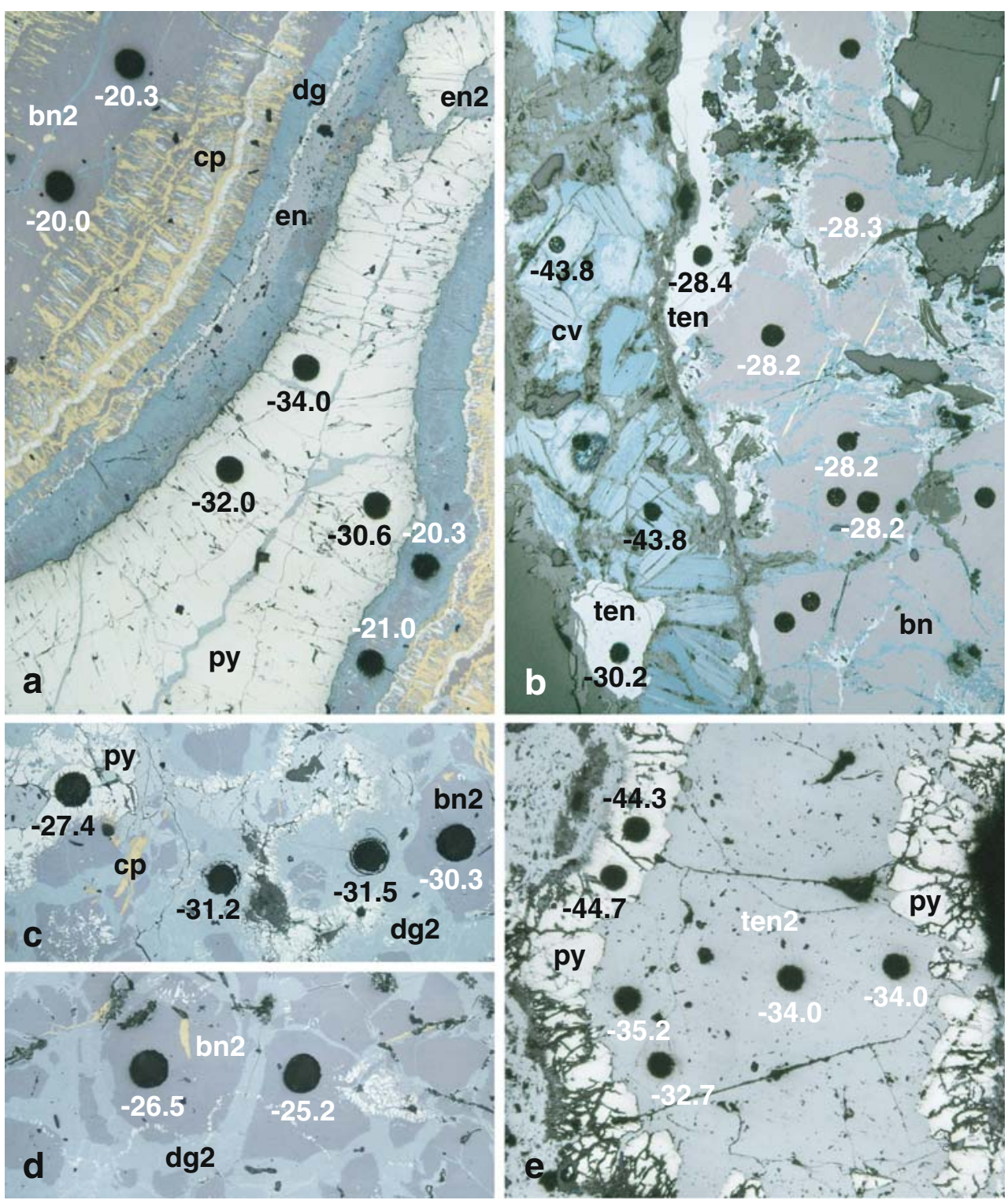

(average, 11\%o) in the center and distinctly negative $\delta^{34} \mathrm{~S}$ values (average, $-28 \%$ ) at the rim.

Apart from the large isotopic variability within a single deposit and among different mineralization styles, we have also observed significant differences in isotope composition between adjacent minerals of up to $11 \%$ o (e.g., between tennantite, pyrite, and enargite). For about one third of these minerals, statistically significant isotopic variation within a single grain (of up to $6 \%$ ) was observed, exceeding our analytical precision that is in the range of $0.5-1.0 \%$.

Conventional sulfur isotope analysis was performed on 78 barite samples (from 33 different localities) covering the principal vein-type mineralization of the Spessart (both $\mathrm{Cu}-\mathrm{Co}-\mathrm{Ni}-\mathrm{As}$ ore veins and barren barite veins). The results are summarized in Table 6 and plotted in Fig. 8. The $\delta^{34} \mathrm{~S}$ values of the barite show a considerable variation between $4.7 \%$ and $18.9 \%$, but a relatively tight average of $10.1 \pm$
$2.2 \%$. The variation between barite-bearing veins hosted by the three principal lithological units (the crystalline basement, Zechstein dolomite, and Bunter Sandstone) is comparatively small (Fig. 8). The $\delta^{34} \mathrm{~S}$ values of barite from the crystalline

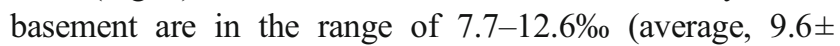
$1.4 \%$ ), with a distinct maximum around 8-9\%o. Compared to veins hosted by the crystalline basement (and the Permian rhyolite), the barite veins and impregnations in the Zechstein dolomite show a larger variation in $\delta^{34} \mathrm{~S}$ ranging from $7.0 \%$ to $12.9 \%$ (average, $10.5 \pm 1.2 \%$ ) and a maximum that is slightly shifted to more positive values of around $10-11 \%$ (Fig. 8). Three data points from the Bieber deposit originating from barite veins that contain substantial amounts of Mn-siderite have unusually high $\delta^{34} \mathrm{~S}$ values of $16.9-18.9 \%$. The barite veins from the Bunter Sandstone have $\delta^{34} \mathrm{~S}$ values in the range between $6.6 \%$ and $12.9 \%$ (average, $8.9 \pm 1.5 \%$ ) and two distinct maxima 
Fig. 5 Photomicrographs in reflected light showing representative textures of vein-type ore mineralization (type 3), Bieber deposit, with superposed $\delta^{34} \mathrm{~S}$ values (\%o). a Sulfide minerals of the $\mathrm{Cu}$ stage. Pyrite $(p y)$ is surrounded by tennantite (ten) that contains chalcopyrite $(c p)$ inclusions. Sample: BIE149. Width of field: $1.6 \mathrm{~mm}$. b Sulfide minerals of the $\mathrm{Cu}$ stage. Coarse-grained tennantite with chalcopyrite inclusions. Sample: BIE-149. Width of field: $300 \mu \mathrm{m}$. c Emplectite $(e p l)$ of the late stage with inclusions of safflorite (saf). Sample: BIE-151a. Width of field: $550 \mu \mathrm{m}$. d Fractures in brecciated tennantite of the $\mathrm{Cu}$ stage are filled by later barite and anhedral to subhedral crystals of marcasite $(m c)$. Sample BIE-452a. Width of field: $1.5 \mathrm{~mm}$

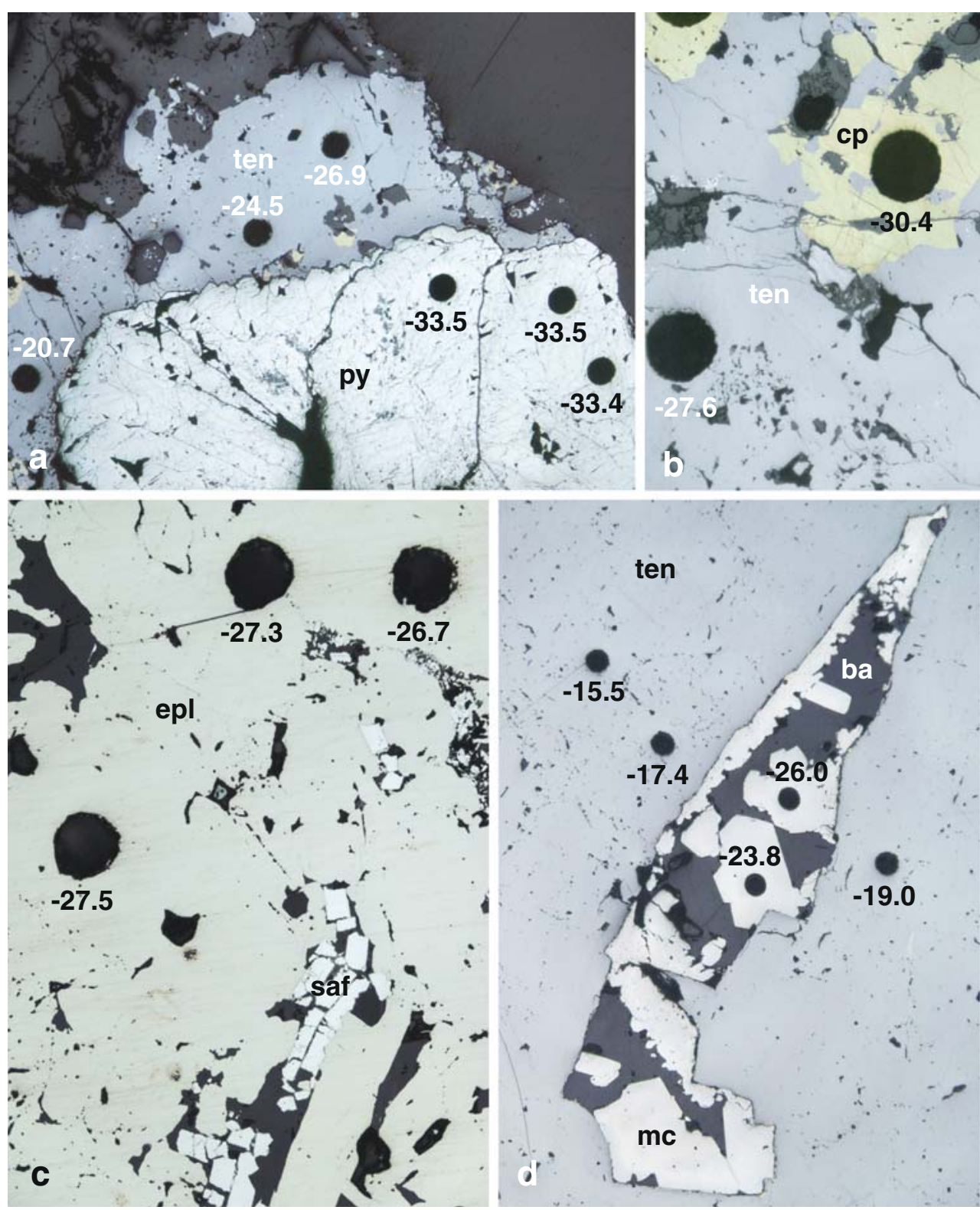

around $7-8$ and $10-11 \%$, respectively (Fig. 8). We have not detected any correlation between the sulfur isotope composition and the $\mathrm{Sr}$ concentration in the barite, despite the occurrence of the barite veins in different host rock lithologies characterized by highly variable sulfur and strontium abundances.

\section{Discussion and conclusions}

The results of our sulfur isotope study place important constraints on the genetic link between the different mineralization styles (stratabound, structurally controlled, and vein-type) and the processes that were responsible for ore formation. The most striking features of the sulfur isotope data set are the consistently negative and highly variable $\delta^{34} \mathrm{~S}$ values of the sulfide minerals. These are in the range between $-44.5 \%$ and $-3.9 \%$, with two distinct modes occurring at $-36 \%$ to $-28 \%$ and $-12 \%$ o to $-6 \%$ (Fig. 7). The data that cluster in the range between $-36 \%$ and $-28 \%$ are very similar to the data for diagenetic pyrite and base metal sulfides (Fig. 9) that were reported from stratabound Kupferschiefer-hosted mineralization in Germany and Poland (Marowsky 1969; Sawlowicz 1989; Jowett et al. 1991a; Sawlowicz and Wedepohl 1992; Bechtel et al. 2001; Krouse et al. 2006). Taking these data into consideration, the sulfur isotope data for the base metal mineralization in the Spessart would suggest mixing between two principal sulfur sources. One of these sources would be sedimentary-diagenetic in origin with very negative $\delta^{34} \mathrm{~S}$ values close to the sulfides in the Kupferschiefer, whereas the second source that is characterized by 


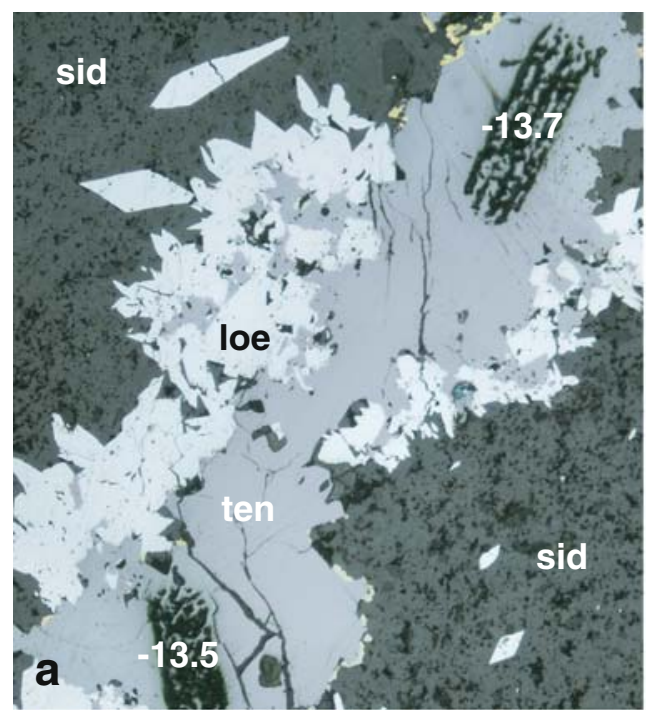

Fig. 6 Photomicrographs in reflected and transmitted light showing representative textures of sulfide metasomatic Mn-siderite ores (type 4) and sulfide-bearing barite veins (type 5). a Anhedral tennantite (ten), surrounded by subhedral to euhedral loellingite (loe) in Mn-siderite (sid). Metasomatic Mn-siderite ore, Bieber mining area.

significantly less negative $\delta^{34} \mathrm{~S}$ values is likely to be of hydrothermal origin. The bulk of the data, in particular those from the vein-type mineralization (type 3), is consistently negative, indicating a predominance of sulfur derived from the sedimentary-diagenetic source.

\section{Sources of sulfide sulfur}

The most straightforward model to facilitate mixing between both sulfur sources at the basement-cover interface would involve upward migration of hydrothermal fluids and interaction with sedimentary-diagenetic sulfides in the Kupferschiefer and the Zechstein dolomite. Such a model has been proposed for the formation of the main Kupferschieferhosted base metal deposits. It involves migration of late diagenetic to low-temperature hydrothermal brines derived from the Lower Permian volcanics and redbed sedimentary rocks into the Kupferschiefer and direct replacement of diagenetic pyrite by base metal sulfides (Jowett 1986; Cathles et al. 1993; Wedepohl and Rentsch 2006). Comprehensive evidence for this model comes from textural observations (Sawlowicz and Wedepohl 1992), basin-scale metal zoning patterns (Wedepohl and Rentsch 2006), geochronological information (Jowett et al. 1987; Bechtel et al. 1999; Wedepohl and Rentsch 2006), and the consistent sulfur isotope shift of the base metal sulfides towards more positive values compared to precursor pyrite (Marowsky 1969; Jowett et al. 1991b).

Application of this model to the base metal mineralization in the Spessart faces several important chemical and physical problems. The most important issue is that stratabound (type

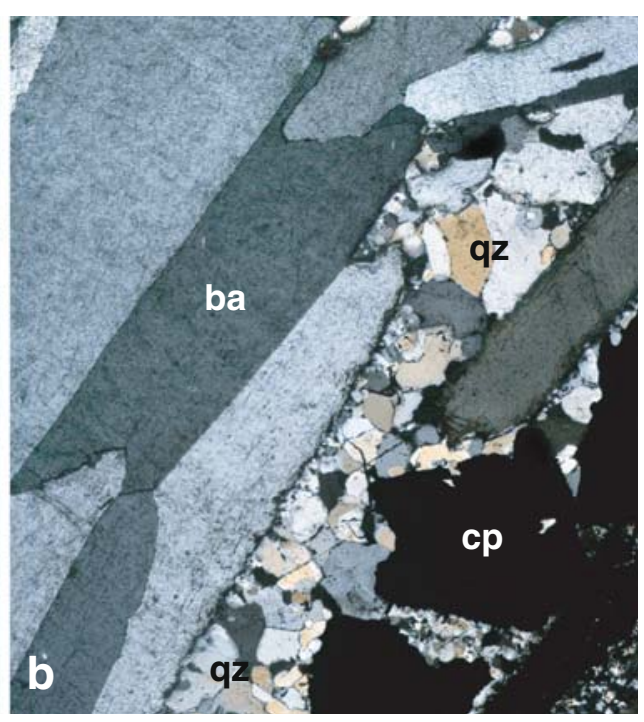

Sample: Sp06-84. Width of field: $650 \mu \mathrm{m}$. b Framework of coarsegrained tabular barite $(b a)$ crystals, with the interstices filled by two generations of quartz $(q z)$ and chalcopyrite $(c p)$. Sulfide-bearing barite vein, Pauline mine (Waldaschaff). Transmitted light, crossed polars. Sample: JL293-39. Width of field: $4.0 \mathrm{~mm}$

1) and structurally controlled (type 2) mineralization styles in Zechstein sediments have the least negative $\delta^{34} \mathrm{~S}$ values in the range between $-20.3 \%$ and $-3.9 \%$, with a clear mode around $-8 \%$ (Fig. 7). Conversely, all major vein-type (type 3) hydrothermal deposits (e.g., those at Sommerkahl and Bieber) have substantially more negative $\delta^{34} \mathrm{~S}$ values, suggesting that the sulfur isotope budget in these deposits is dominated by sedimentary-diagenetic sulfur derived from the Kupferschiefer (Fig. 9). The observed correlation between mineralization style and sulfur isotope data is reversed compared to what would be expected from direct interaction between hydrothermal fluids and sediment hosted sulfides.

Hydrothermal fluids that migrate upward along major fault systems and then interact with the Zechstein sedimentary rocks should precipitate sulfides very efficiently. This is because fault-related fluids that likely originate as deep groundwater in the crystalline basement (Stober and Bucher $1999 b, 2005$, 2007) will probably have a $\mathrm{pH}$ close to neutral (Stober and Bucher 1999b), and reaction with the Zechstein dolomite will shift the fluid $\mathrm{pH}$ to more alkaline. A shift in $\mathrm{pH}$ by at least 2 units will result in a substantial drop in the solubility of all base metals by several $\log$ units that will cause efficient ore mineral precipitation (Seward and Barnes 1997). This mechanism effectively works for $\mathrm{Pb}, \mathrm{Zn}, \mathrm{Co}, \mathrm{Ni}$, $\mathrm{Cu}$, and $\mathrm{Ag}$, which are all dominantly transported as chloride complexes in saline hydrothermal fluids of moderate temperature (Seward and Barnes 1997; Shock et al. 1997; Sverjensky et al. 1997; Wood and Samson 1998).

As a consequence, the sulfur isotope data of the precipitated sulfide minerals should become increasingly more close to the hydrothermal values with proximity to the 

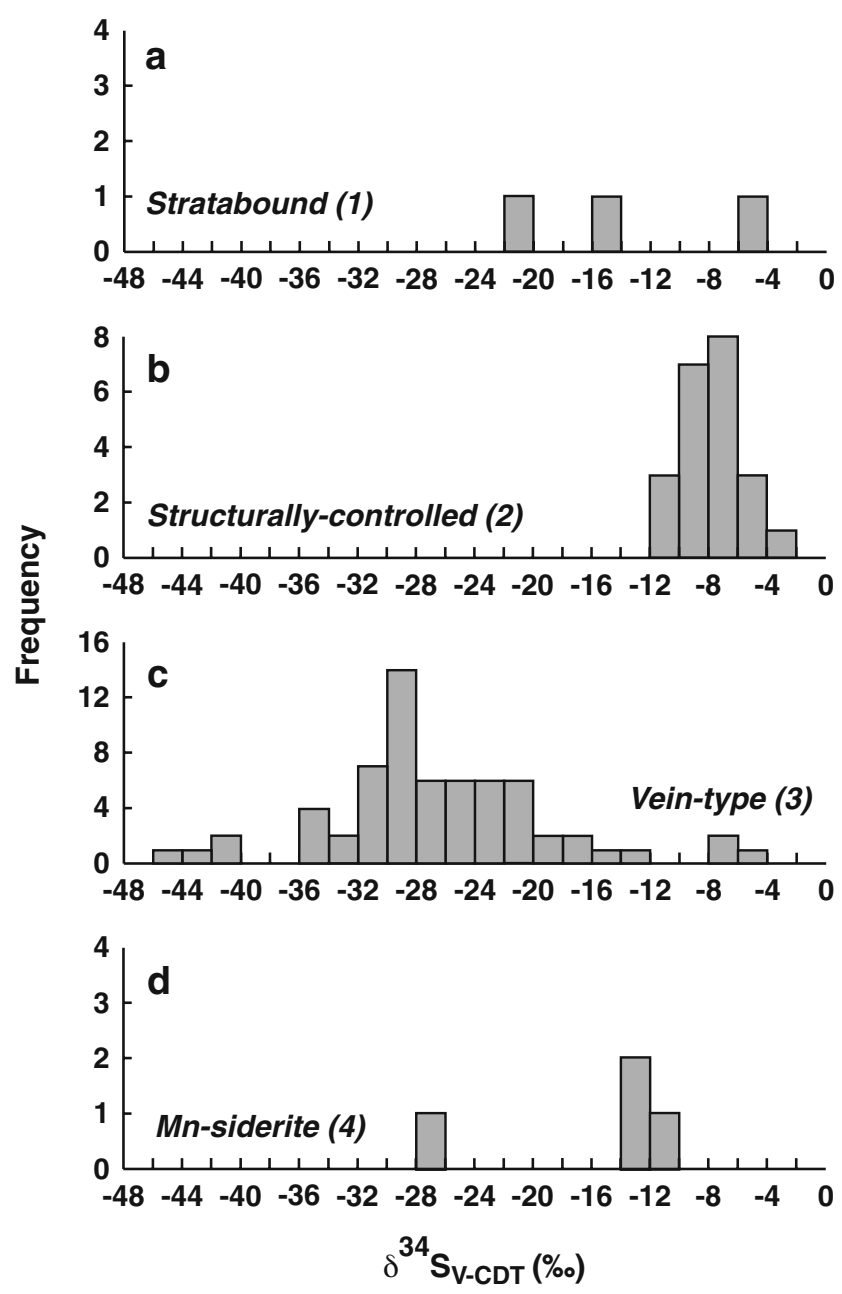

Fig. 7 Histograms displaying sulfur isotope data of sulfide minerals from different mineralization styles, Spessart district. a Stratabound mineralization (type 1), b structurally controlled mineralization in Zechstein sedimentary rocks (type 2), c vein-type mineralization (type 3 ), and $\mathbf{d}$ metasomatic Mn-siderite ores (type 4)

hydrothermal veins. Only where fluids can percolate along fracture networks into the Zechstein sedimentary rocks they are able to directly react with the sedimentary-diagenetic sulfides, resulting in $\delta^{34} \mathrm{~S}$ values more close to the primary sedimentary-diagenetic values. Direct reactive leaching of sulfur from the Zechstein sedimentary rocks is not consistent with the above thermodynamic considerations. Such a process would require that the fluids are strongly undersaturated with sulfide minerals when they interact with disseminated sulfides in the Zechstein rocks. Because the Zechstein rocks contain substantial amounts of carbonate, reaction of fluids having near-neutral $\mathrm{pH}$ with carbonate will invariably shift the fluid $\mathrm{pH}$ to more alkaline values. This would then result in greatly reduced solubility of pyrite and base metal sulfides, hence no efficient leaching and transport of sulfur would be possible without invoking unreasonably large volumes of fluids.
Fluid mixing at the basement-cover interface

Because models for fluid-rock interaction as conventionally applied to base metal mineralization in the Kupferschiefer are not able to explain our data from the Spessart district, we propose a modified fluid mixing model for this setting (Fig. 10). The central idea is that the basement-cover interface (the unconformity between the crystalline basement and the overlying Zechstein sedimentary rocks) is the principal locus for episodic interaction of two different fluid flow regimes that are largely decoupled. One fluid regime is essentially confined to the continuous stratigraphy of the sedimentary cover rocks. The Kupferschiefer and other shales in the Zechstein (in particular the Bröckelschiefer), which are at the bottom of the post-Variscan sedimentary cover, have very low permeability and effectively act as a hydraulic seal that isolates the fluid reservoir above from the reservoir in the underlying crystalline basement. Fluid flow in the sedimentary cover will be essentially subhorizontal, either compaction-driven resulting from large-scale dewatering of deeper parts of the Mesozoic basin or gravity-driven as a consequence of the onset of basin inversion (Garven et al. 1993; Muchez et al. 1994; Person et al. 1996; Wilson et al. 2000; Schmidt-Mumm and Wolfgramm 2002, 2004; Oliver et al. 2006). Groundwaters that migrate within the cover sequence will be in thermal and chemical equilibrium with the Zechstein sedimentary rocks, close to dolomite saturation and probably also close to pyrite saturation. The reduced sulfur budget of these groundwaters is therefore derived from dissolution of sedimentary-diagenetic pyrite of the Zechstein sedimentary rocks with consistently negative sulfur isotope compositions (Marowsky 1969; Jowett et al. 1991a). Part of this sulfur budget might also come from sulfur bound in organic matter of the Kupferschiefer and bituminous Zechstein dolomite, which has also quite negative $\delta^{34} \mathrm{~S}$ values in the range between $-34 \%$ and $-19 \%$ (Bechtel et al. 2001).

The second fluid system is fluids that originate as deep groundwater in the crystalline basement (Fritz and Frape 1982; Nurmi et al. 1988; Lodemann et al. 1997; Stober and Bucher 1999a, b, 2004, 2005). The ultimate source of these fluids cannot be resolved, because they might have originally formed via ingression of formation waters from deeper parts of the Mesozoic basin into the underlying basement (Gleeson et al. 2000, 2003; Boiron et al. 2002) or from old groundwater that was stored in the crystalline basement (Stober and Bucher 1999b, 2004). Because the Zechstein shales at the base of the post-Variscan cover effectively act as a hydraulic seal, the fluid reservoir in the crystalline basement will be overpressured. Activation of subvertical major post-Variscan faults will then result in episodic release of large volumes of these overpressured fluids and very rapid upward migration. It is known from 
Table 6 Average strontium concentrations (with $1 \sigma$ standard deviations) and sulfur isotope data of hydrothermal barite hosted in crystalline basement, Zechstein sedimentary rocks, and Bunter Sandstone, Spessart district, Germany

\begin{tabular}{llll}
\hline Sample & Locality & Sr (mol.\%) & $\delta^{34} \mathrm{~S}_{\mathrm{V}-\mathrm{CDT}}(\%)$ \\
\hline
\end{tabular}

\section{Crystalline basement}

JL50-201

JL50-203

JL50-204

JL50-206

Sp06-62

JL146-5

JL141-5

JL141-6

JL293-39

JL293-40

JL293-41

JL293-42

JL302-9

JL302-10

JL302-11

JL302-12

JL314-1

JL38-16

JL38-17a

JL313-3

JL139-4

JL139-5

JL309-1

JL309-2

JL31-2

JL31-3

JL31-4

JL23-129

JL23-131

JL259-6

JL259-7

JL32-492

JL32-494

JL32-495

JL32-499

Zechstein sedimentary rocks

$\begin{array}{lll}\text { JL271-59 } & 15 & 8.6(0.3) \\ \text { JL271-60 } & 15 & 4.5(1.6) \\ \text { JL271-63 } & 15 & 7.5(0.3) \\ \text { JL57-4 } & 16 & 9.3(0.4) \\ \text { JL57-5 } & 16 & 8.8(0.3) \\ \text { JL58-1 } & 17 & 7.4(1.2) \\ \text { JL269-5 } & 18 & 6.8(0.6) \\ \text { JL145-4 } & 19 & 4.9(1.1) \\ \text { JL145-5 } & 19 & 5.1(1.9)\end{array}$

Table 6 (continued)

\begin{tabular}{|c|c|c|c|}
\hline Sample & Locality & $\mathrm{Sr}(\mathrm{mol} . \%)$ & $\delta^{34} \mathrm{~S}_{\mathrm{V}-\mathrm{CDT}}(\% \mathrm{o})$ \\
\hline JL145-6 & 19 & $4.0(1.7)$ & 9.5 \\
\hline JL300-7 & 20 & $7.0(1.1)$ & 11.3 \\
\hline JL300-10 & 20 & $6.5(0.3)$ & 10.3 \\
\hline JL311-1 & 21 & $8.7(0.3)$ & 10.7 \\
\hline JL7-20 & 22 & $6.7(0.8)$ & 10.7 \\
\hline JL7-21 & 22 & $6.6(3.8)$ & 7.0 \\
\hline JL161-5 & 23 & $3.6(2.9)$ & 12.9 \\
\hline JL67-2 & 25 & $5.2(1.2)$ & 11.3 \\
\hline JL307-1 & 26 & $5.8(2.2)$ & 11.3 \\
\hline JL294-12 & 28 & $2.8(1.4)$ & 17.1 \\
\hline JL294-14 & 28 & $4.5(0.8)$ & 18.9 \\
\hline JL174-32 & 29 & $3.5(1.9)$ & 11.5 \\
\hline JL174-33 & 29 & $1.2(0.6)$ & 11.1 \\
\hline JL174-34 & 29 & $4.6(0.7)$ & 16.9 \\
\hline JL295-19 & 30 & $4.9(1.1)$ & 12.2 \\
\hline JL262-5 & 32 & $0.6(1.9)$ & 10.5 \\
\hline JL295-23 & 30 & $6.8(3.6)$ & 7.9 \\
\hline JL295-24 & 30 & $0.5(0.5)$ & 11.2 \\
\hline \multicolumn{4}{|c|}{ Bunter Sandstone } \\
\hline JL304-4 & 33 & $5.1(1.9)$ & 10.7 \\
\hline JL304-5 & 33 & $7.6(0.1)$ & 10.0 \\
\hline JL304-6 & 33 & $5.6(1.1)$ & 8.3 \\
\hline JL304-7 & 33 & $4.3(1.7)$ & 8.4 \\
\hline JL304-8 & 33 & $4.9(0.3)$ & 8.3 \\
\hline JL113-2 & 34 & $3.9(0.5)$ & 6.6 \\
\hline JL113-2a & 34 & ND & 7.9 \\
\hline JL113-3 & 34 & $3.4(0.9)$ & 7.6 \\
\hline JL113-4 & 34 & $2.1(0.9)$ & 7.5 \\
\hline JL113-5 & 34 & $5.5(1.1)$ & 8.1 \\
\hline JL112-3 & 35 & $5.5(1.3)$ & 10.4 \\
\hline JL112-4 & 35 & $1.8(1.9)$ & 11.3 \\
\hline JL112-5 & 35 & $5.1(2.5)$ & 10.3 \\
\hline JL316-1 & 36 & $5.2(0.5)$ & 10.8 \\
\hline JL316-2 & 36 & $5.0(1.1)$ & 10.2 \\
\hline JL316-3 & 36 & $1.9(0.9)$ & 12.9 \\
\hline
\end{tabular}

studies of recently active major normal and strike-slip fault systems that fluid ascent from several kilometers depth occurs quite rapidly, i.e., in weeks to several months (Muir-Wood and King 1993; Koerner et al. 2004; Miller et al. 2004). Following seismically active periods, i.e., during periods of coseismic strain collapse of fracture networks (Muir-Wood and King 1993) or seismic aftershock sequences (Sibson 2000; Miller et al. 2004), deep groundwater migrating upward in the post-Variscan fault zones can be injected into the fluid that is present in the Zechstein sedimentary rocks. 

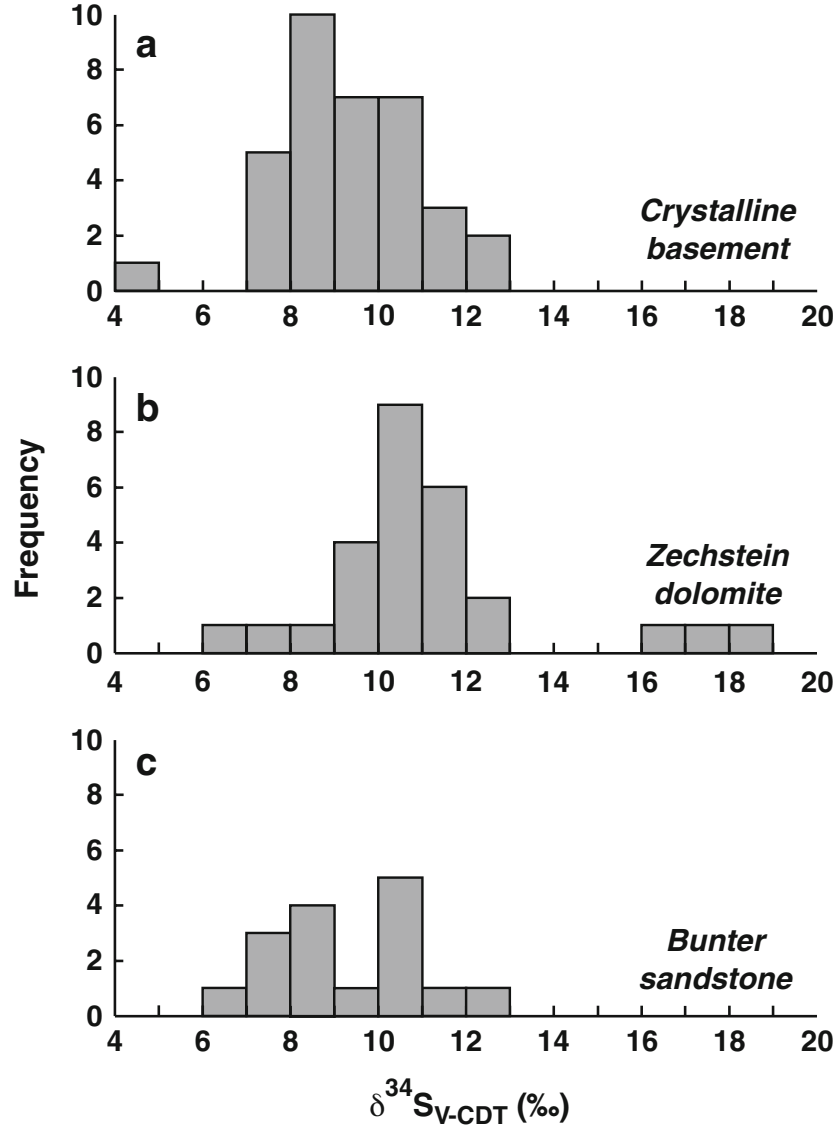

Fig. 8 Histograms displaying sulfur isotope data of barite from veintype mineralization, Spessart district. a Data from the veins hosted in the crystalline basement, $\mathbf{b}$ data from veins in Zechstein dolomite and metasomatic Mn-siderite, and $\mathbf{c}$ data from veins in the Bunter Sandstone

The rapid fluid mixing at the basement-cover interface results in a large chemical contrast, because the fluids that originate from the crystalline basement will be substantially hotter and have a pH close to neutral (Lodemann et al. 1997; Stober and Bucher 1999b, 2005; Möller et al. 2005). By contrast, the fluids in the Permian-Mesozoic cover are much cooler and have an alkaline $\mathrm{pH}$ (Minissale et al. 2002; Schmidt-Mumm and Wolfgramm 2002, 2004). This will result in a substantial drop of base metal solubility and efficient precipitation of sulfide ore minerals. Because the precipitation process occurs relatively fast, the dissolved aqueous sulfides will be in gross disequilibrium with the sulfates (Ohmoto and Lasaga 1982; Ohmoto and Goldhaber 1997), hence the sulfur isotope composition of the sulfide minerals will be close to the reduced sedimentary sulfur. Conversely, the sulfur isotope data of the barites will largely reflect the composition of the dissolved sulfate.

The $\delta^{34} \mathrm{~S}$ values of the hydrothermal sulfides from veintype mineralization (type 3 ) are consistently negative, but they show considerable variation, both on the deposit and sample scale. This variation can be essentially explained by contributions of reduced sulfur from the deep-sourced hydrothermal fluids and those fluids that migrated in the sedimentary cover sequence. Although the sulfur isotope composition of the reduced sulfur in these fluids is not known, comparison with other post-Variscan mineralization in Germany suggests that they would have moderately negative to positive $\delta^{34} \mathrm{~S}$ values (e.g., Zheng and Hoefs 1993; Schwinn et al. 2006). Repeated and variable fluid mixing would result in ore sulfide $\delta^{34} \mathrm{~S}$ values that are highly variable in time and space, fully consistent with our data and observations. Alternatively, fluid mixing might have resulted in formation of reduced sulfur via thermochemical sulfate reduction (TSR) (Machel et al. 1995; Machel 2001). Because the TSR process involves only a small sulfur isotope fractionation (Machel et al. 1995; Jones et al. 1996; Warren 2000; Machel 2001), the reduced sulfur produced would be quite close to the original dissolved aqueous sulfate. Variable mixing between reduced sulfur from the sedimentary fluids (having consistently negative $\delta^{34} \mathrm{~S}$ values) and reduced sulfur produced via TSR (having moderately positive $\delta^{34} \mathrm{~S}$ values) could also explain the observed large variation in the vein-type deposits. The sulfur isotope data do not allow to discriminate between these two end-member scenarios (simple mixing or mixing plus TSR) or a combination of both. The abundance of reduced arsenic (present as arsenide minerals or tennantite) in the vein-type (type 3 ) and structurally controlled (type 2) mineralization would suggest that thermochemical arsenite reduction (Blair 1997; Wagner and Lorenz 2002) and TSR were involved into ore formation.

We have observed that the $\delta^{34} \mathrm{~S}$ values of the structurally controlled (type 2) base metal mineralization (HuckelheimGrosskahl area) are consistently less negative than those of the major vein-type deposits (type 3 ). This unusual feature can be explained within the framework of our modified fluid mixing model if the dynamic nature of fluid flow is taken into consideration. The tectonic activation of the postVariscan fault zones likely results in the release of large amounts of fluids within a short period of time. These fluids are initially injected onto the aquifers of the PermianMesozoic cover sequence, and rapid and efficient mixing at the basement-cover interface results in substantial ore deposition in major veins and fault zones. As long as large fluid flow rates in the faults and veins are maintained, the basement-derived fluids will progressively infiltrate smallscale fracture networks in the adjacent Zechstein rocks. This migration into the Zechstein rocks will then cause minor ore precipitation due to reaction with carbonate, where the chemical and isotopic composition of the sulfide minerals is largely controlled by the signature of the basement-derived hydrothermal fluids. 
Fig. 9 Comparison of the sulfur isotope data of sulfides from the Spessart district with other postVariscan ore deposits and mineralizations in Central Europe. a Spessart district; data from this study. b Schwarzwald district; data from Schwinn et al. (2006). c Harz district; data from Zheng and Hoefs (1993). d Primary pyrite in the Kupferschiefer mineralization; data from Marowsky (1969) and Jowett et al. (1991a). e Base metal sulfides in the

Kupferschiefer mineralization; data from Marowsky (1969), Sawlowicz (1989), Jowett et al. (1991a, b), Sawlowicz and Wedepohl (1992), and Krouse et al. (2006)
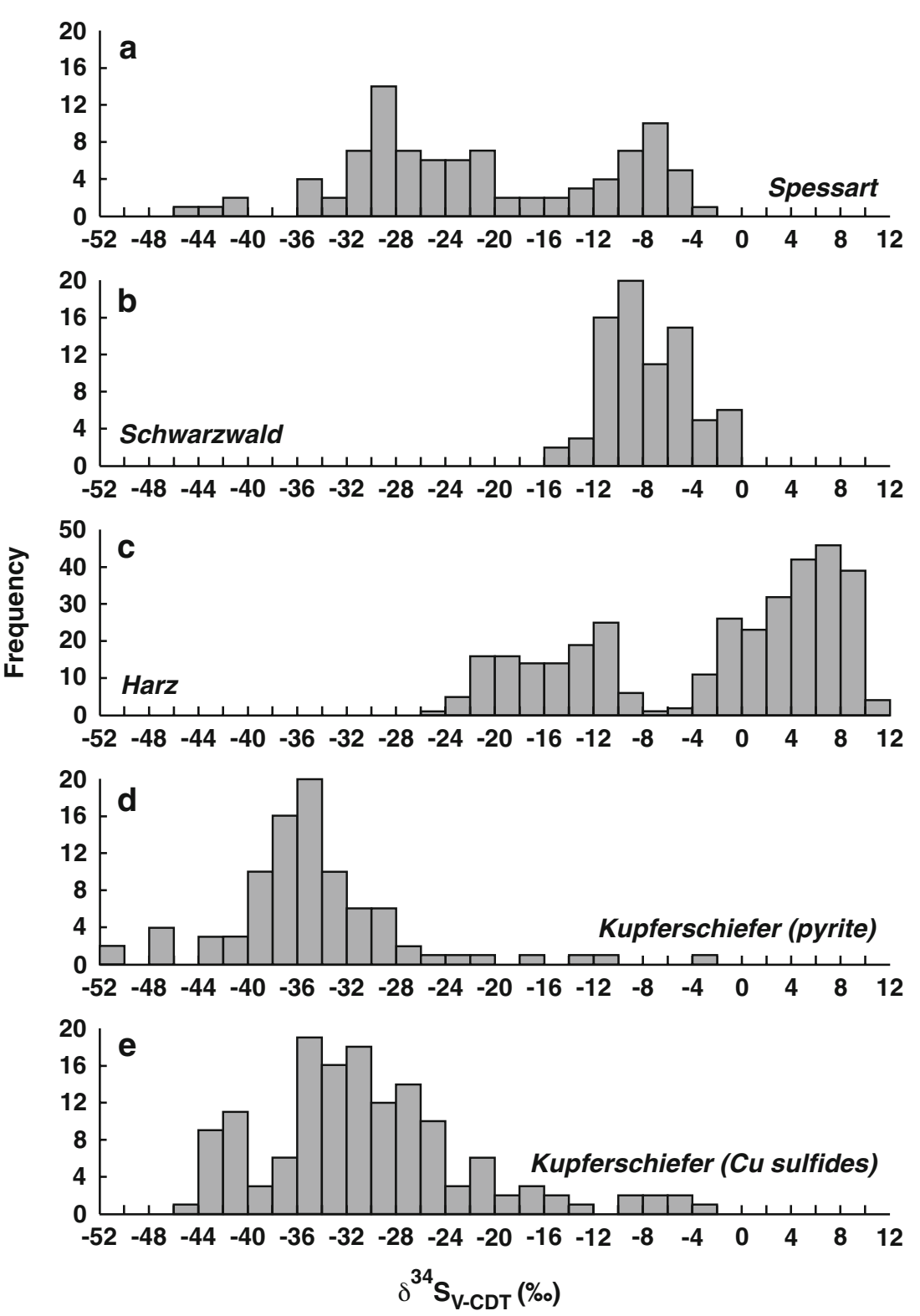

Sources of sulfate

The $\delta^{34} \mathrm{~S}$ values of barite from vein-type mineralization (both $\mathrm{Cu}-\mathrm{Co}-\mathrm{Ni}-\mathrm{As}$ ore veins and barren barite veins) in the Spessart are mostly in the range between $7.3 \%$ and $12.9 \%$, with a clear mode around 9-11\% (Fig. 11). Only three barite samples from the Bieber deposit have substantially higher $\delta^{34} \mathrm{~S}$ values between $16.9 \%$ and $18.9 \%$. The mode of the Spessart barite data overlaps with the typical composition of evaporitic rocks of the Zechstein, which show a well-defined and narrow range in $\delta^{34} \mathrm{~S}$ values between 9.7\% and 12.6\%o (Kramm and Wedepohl 1991; Kampschulte et al. 1998). This suggests that the majority of dissolved sulfate in the hydrothermal fluids that formed the base metal mineralization in the Spessart was derived from groundwaters that had interacted with Zechstein evaporites. Compared to the well-defined isotopic composition of the Zechstein evaporites, the $\delta^{34} \mathrm{~S}$ values of hydrothermal barite in the Spessart are considerably more variable. Those barite data that are more positive than the average Zechstein sulfates can be well explained through contributions of sulfate that originated from Mesozoic rocks. The $\delta^{34} \mathrm{~S}$ values of Mesozoic evaporites are considerably more positive than those of the Zechstein sedimentary rocks (Fig. 11) and lie in the range between $12.2 \%$ and $20.8 \%$ (Müller et al. 1966; Rick 1990). The evaporites of the 


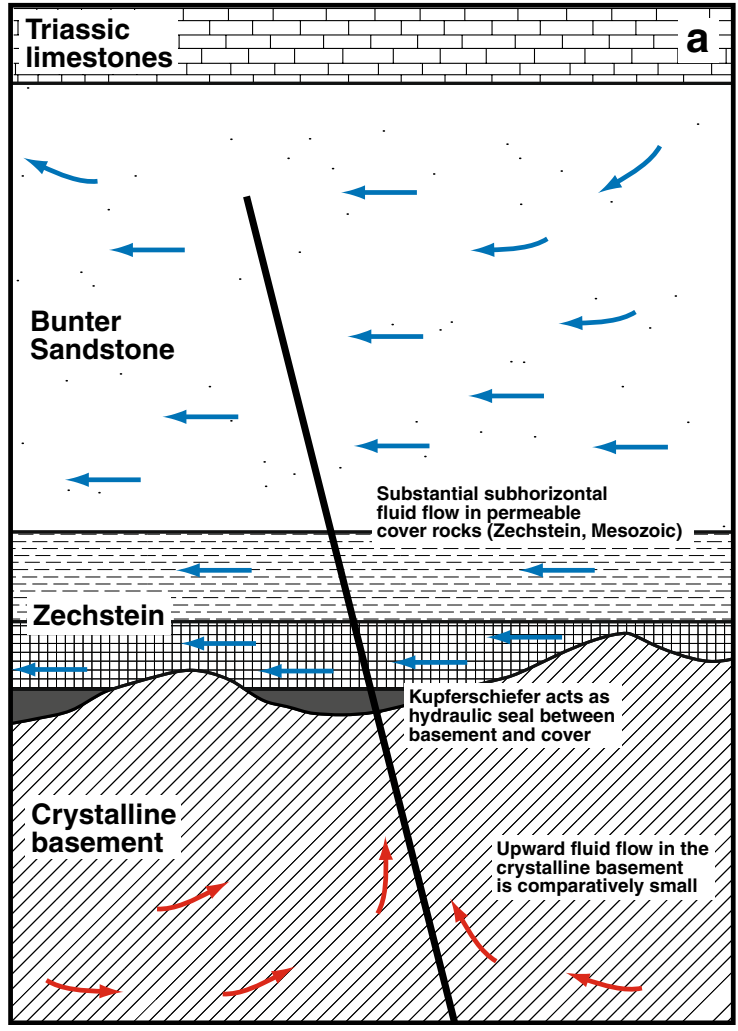

Fig. 10 Cartoon showing our envisaged model of fluid mixing at the basement-cover interface. a During periods when major fault zones are inactive, major fluid flow is confined to the permeable sedimentary rocks of the cover sequence that are separated from the crystalline basement by rather impermeable strata. Fluid flux within the crystalline basement is comparatively small. b When major fault

Muschelkalk that directly overlies the Bunter Sandstone have the most positive $\delta^{34} \mathrm{~S}$ values in the range between 17.8\%o and 20.8\%o (Müller et al. 1966). The barite data that are less positive than the composition of the Zechstein evaporites are likely related to contributions of isotopically light sulfur from oxidation of sulfides in the source region. The $\delta^{34} \mathrm{~S}$ values of disseminated pyrite in the Zechstein evaporites are in the range between $-22.5 \%$ and $-20.6 \%$ (Kampschulte et al. 1998). Because of the large compositional difference between evaporitic sulfates and disseminated pyrites in the Zechstein sedimentary rocks, only a small contribution of isotopically light sulfur would be required to explain the observed variation.

Comparison with other post-Variscan vein deposits

Additional support for our modified fluid mixing model comes from comparison of the base metal mineralization in the Spessart with other post-Variscan ore districts in Germany. Most importantly, the data of post-Variscan veins from the

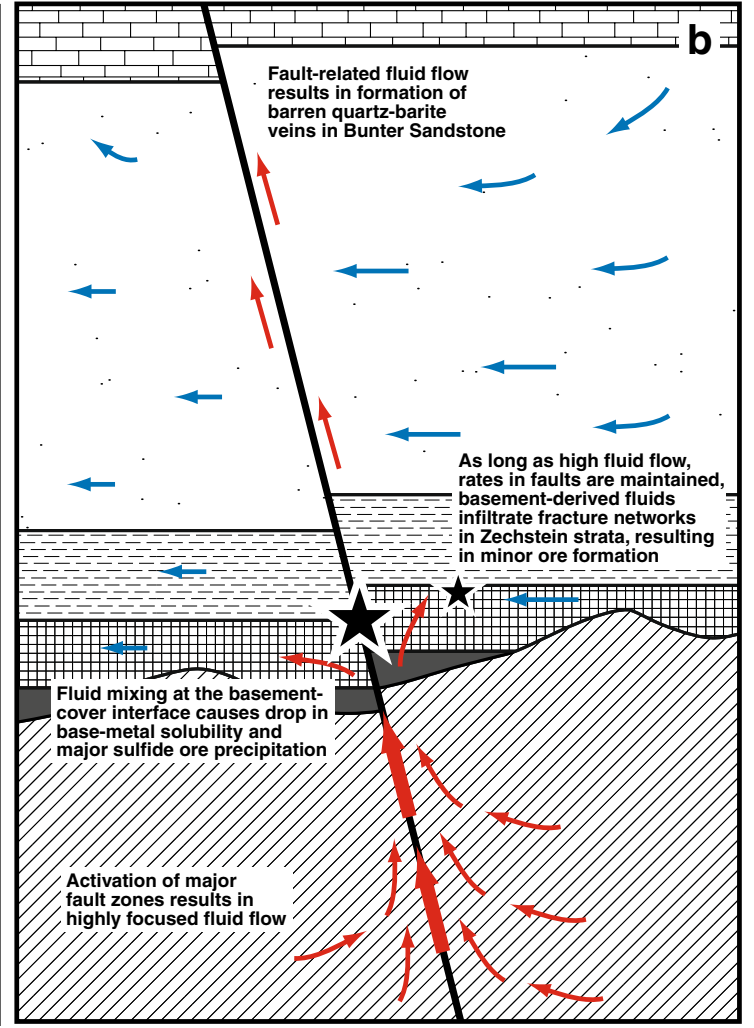

zones become active, they focus large volumes of fluid that flow upwards driven by a strong pressure gradient. This fluid mixes with chemically contrasting fluids migrating in the cover sequence, resulting in efficient ore precipitation and highly variable sulfur isotope data of hydrothermal sulfides

Schwarzwald are slightly negative (Schwinn et al. 2006) but do not reach such extreme values as our data from the Spessart (Fig. 9). This difference can be directly correlated with the first-order geological features of both areas. In the Schwarzwald area, the crystalline basement is directly and unconformably overlain by the Bunter Sandstone. Permian siliciclastic sedimentary rocks are present in some small intramontane basins, but no sedimentary rocks of Zechstein age were deposited in the Schwarzwald (van Wees et al. 2000). Therefore, the fluids that were migrating in the lowermost part of the post-Variscan cover sequence could not interact with substantial amounts of isotopically negative sedimentary sulfur. This is directly manifested by the $\delta^{34} \mathrm{~S}$ values of hydrothermal sulfides that are largely in a narrow range between $-12 \%$ and $-4 \%$. Conversely, the data from the Harz district show a distinctly bimodal distribution that correlates with the location of the ore deposits (Fig. 9). While sulfides from vein-type ore deposits in the upper and lower Harz have $\delta^{34} \mathrm{~S}$ values in the range between $-4 \%$ and $12 \%$, the $\delta^{34} \mathrm{~S}$ values of deposits in the middle Harz are 

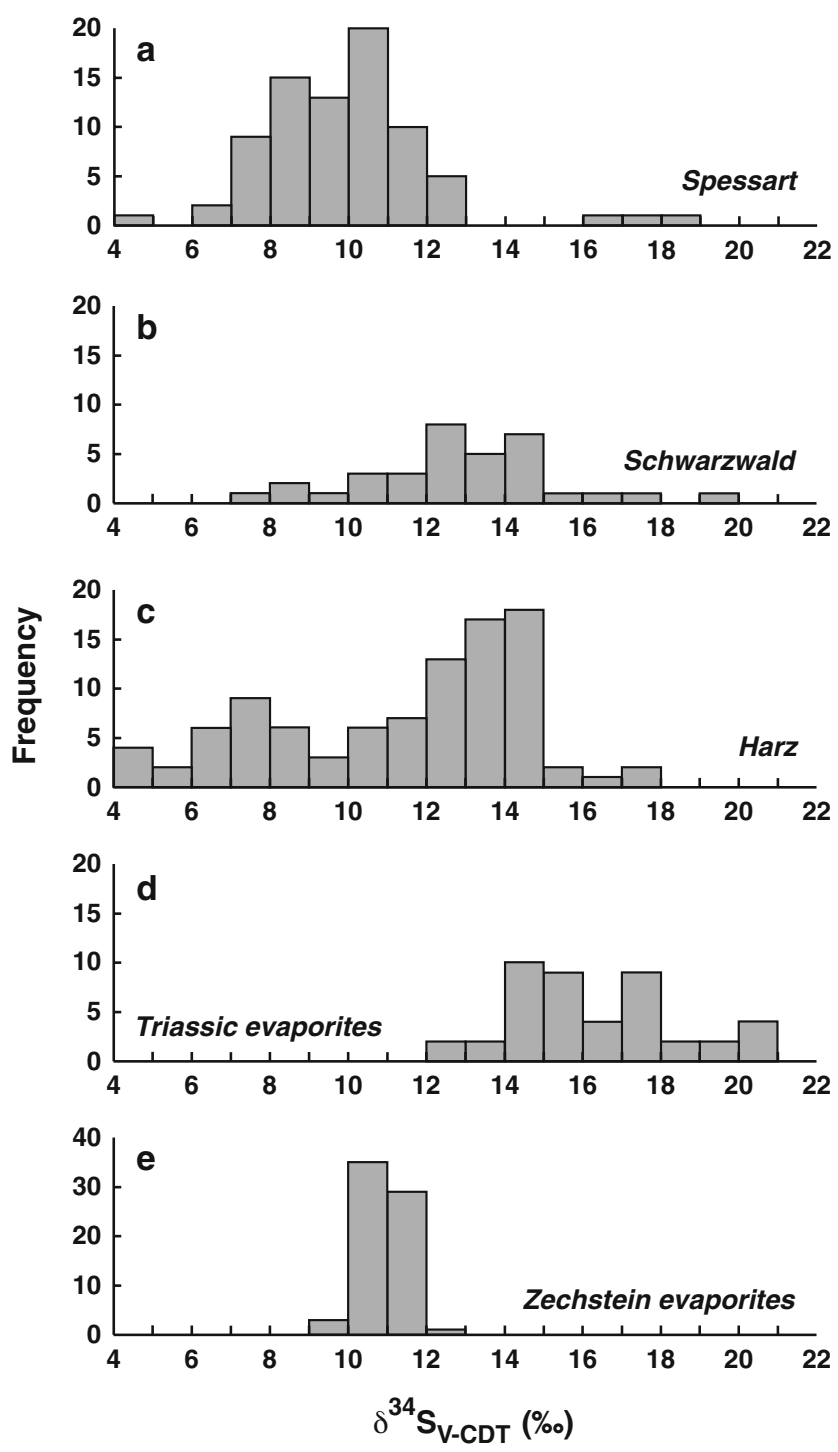

Fig. 11 Comparison of the sulfur isotope data of barite from the Spessart district with other post-Variscan ore deposits in Central Europe and potential evaporitic sulfate sources. a Spessart district; data from this study. b Schwarzwald district; data from Schwinn et al. (2006). c Harz district; data from Zheng and Hoefs (1993). d Mesozoic evaporites; data from Müller et al. (1966) and Rick (1990). e Zechstein evaporites; data from Kampschulte et al. (1998) and Kramm and Wedepohl (1991)

consistently negative in the range between $-20 \%$ and $-10 \%$ o (Zheng and Hoefs 1993). This distribution of data is consistent with substantial involvement of sediment-derived sulfur in the deposits of the middle Harz that likely originated from Zechstein sedimentary rocks, whereas the consistently less negative $\delta^{34} \mathrm{~S}$ values of the deposits in the lower and upper Harz might be related to predominance of TSR-derived sulfur (Zheng and Hoefs 1993). A comparison of the hydrothermal barites from base metal mineralization in the Spessart with those from the Schwarzwald and Harz districts reveals that the data from the Spessart show clearly a closer affinity to the Zechstein evaporites (Fig. 11).

The post-Variscan fluid regime

Integrating the results of our study with data and observations from other base metal districts in Central Europe allows us to explain the formation of hydrothermal mineralization in the Spessart district through a geological model that likely applies to Mesozoic mineralization in major parts of Central Europe as well. This model involves upward migration of fluids that originate from the crystalline basement (Schwinn et al. 2006; Baatartsogt et al. 2007) through fault zones and ore deposition in higher structural levels through fluid mixing processes (e.g., Lüders and Möller 1992; Lüders et al. 1993; Canals and Cardellach 1993; Wilkinson et al. 1995; Markl et al. 2006; Schwinn et al. 2006; Staude et al. 2007). In regions where the continuum between crystalline basement and Permian-Mesozoic cover is well preserved (e.g., Spessart and Schwarzwald districts), it is commonly observed that the upper limit of ore mineralization is defined by the basementcover interface (Staude et al. 2007). This suggests that the basement-cover interface represents a first-order hydrological discontinuity that separates distinct fluid regimes below and above. The upper fluid regime is characterized by largely subhorizontal fluid flow that is essentially dictated by the stratigraphy, whereas the lower fluid regime is controlled by fault activity that periodically releases large amounts of fluids from overpressured reservoirs. The results of our comprehensive sulfur isotope study have provided important insight into the nature of fluid mixing processes at the basement-cover interface and, in particular, have constrained the role of Kupferschiefer-derived fluids in the formation of base metal deposits. A major finding is that although the observed mineralization style and isotopic signatures are largely dependent on second-order features and regional geological setting, the fundamental processes that are responsible for ore formation are essentially comparable for many of the post-Variscan base metal deposits in Central Europe.

Acknowledgements This project was made possible by funding from the German Research Council (DFG). The mineral concentrates were carefully prepared by Maria Kirchenbaur (Würzburg). Uli Schüssler (Würzburg) is thanked for his help and assistance during electron-microprobe analysis. The conventional sulfur isotope analyses were performed with the assistance of Bernd Steinhilber (Tübingen), whose help is gratefully acknowledged. Further thanks are due to Klaus-Peter Kelber (Würzburg) for the microphotographs and Peter Späthe (Würzburg) for the preparation of the polished sections. Adrian Boyce and Bernd Lehmann are thanked for their constructive comments that have helped to improve our paper. 


\section{References}

Baatartsogt B, Schwinn G, Wagner T, Taubald H, Beitter T, Markl G (2007) Contrasting paleofluid systems in the continental basement: a fluid inclusion and stable isotope study of hydrothermal vein mineralization, Schwarzwald district, Germany. Geofluids 7:123147

Bechtel A, Püttmann W (1997) Palaeoceanography of the early Zechstein Sea during Kupferschiefer deposition in the Lower Rhine Basin (Germany): a reappraisal from stable isotope and organic geochemical investigations. Palaeogeogr Palaeoclimatol Palaeoecol 136:331-358

Bechtel A, Elliott WC, Wampler JM, Oszczepalski S (1999) Clay mineralogy, crystallinity, and $\mathrm{K} / \mathrm{Ar}$ ages of illites in the Polish Zechstein Basin: implications for the age of the Kupferschiefer-type mineralization. Econ Geol 94:261-272

Bechtel A, Sun Y, Püttmann W, Hoernes S, Hoefs J (2001) Isotopic evidence for multi-stage metal enrichment in the Kupferschiefer from the Sangershausen Basin, Germany. Chem Geol 176:31-49

Bechtel A, Gratzer R, Püttmann W, Oszczepalski S (2002) Geochemical characteristics across the oxic/anoxic interface (Rote Fäule front) within the Kupferschiefer of the Lubin-Sieroszowice mining district (SW Poland). Chem Geol 185:9-31

Bendall C, Lahaye J, Fiebig J, Weyer S, Brey GP (2006) In-situ sulfur isotope analysis by laser-ablation MC-ICPMS. Appl Geochem 21:782-787

Blair T (1997) Thermochemical arsenite reduction (TAR): a new hypothesis for the origin of "Cobalt-type" Ni-Co-arsenide vein deposits. Unpublished MSc Thesis, McGill University, p 38

Blundell DJ, Karnkowski PH, Alderton DHM, Oszczepalski S, Kucha H (2003) Copper mineralization of the Polish Kupferschiefer: a proposed basement fault-fracture system of fluid flow. Econ Geol 98:1487-1495

Boiron MC, Cathelineau M, Banks DA, Buschaert S, Fourcade S, Coulibaly Y, Michelot JL, Boyce A (2002) Fluid transfers at a basement/cover interfac.e Part II. Large-scale introduction of chlorine into the basement by Mesozoic basinal brines. Chem Geol 192:121-140

Canals A, Cardellach E (1993) Strontium and sulfur isotope geochemistry of low-temperature barite-fluorite veins of the Catalonian Coastal Ranges (NE Spain): a fluid mixing model and age constraints. Chem Geol 104:269-280

Cathles LM, Oszczepalski S, Jowett EC (1993) Mass balance evaluation of the late diagenetic hypothesis for Kupferschiefer $\mathrm{Cu}$ mineralization in the Lubin basin of southwestern Poland. Econ Geol 88:948-956

Dombrowski A, Okrusch M, Henjes-Kunst F (1994) Geothermometry and geochronology on mineral assemblages in orthogneisses and related metapelites of the Spessart Crystalline Complex, NW Bavaria, Germany. Chem Erde 54:85-101

Franke W (2000) The mid-European segment of the Variscides: tectonostratigraphic units, terrane boundaries and plate tectonic evolution. Geol Soc Lond Spec Publ 179:35-61

Fritz P, Frape SK (1982) Saline groundwaters in the Canadian Shield. A first overview. Chem Geol 36:179-190

Garven G, Ge S, Person MA, Sverjensky DA (1993) Genesis of stratabound ore-deposits in the midcontinent basins of North America. 1. The role of regional groundwater-flow. Am J Sci 293:497-568

Giesemann A, Jäger H, Norman A, Brand W (1994) On-line sulfur isotope determination using an element analyzer coupled to mass spectrometer. Anal Chem 66:2816-2819

Gleeson SA, Yardley BWD, Boyce AJ, Fallick AE, Munz IA (2000) From basin to the basement: the movement of surface fluids into the crust. J Geochem Explor 69-70:527-531
Gleeson SA, Yardley BWD, Munz IA, Boyce AJ (2003) Infiltration of basinal fluids into high-grade basement, South Norway: sources and behaviour of waters and brines. Geofluids 3:33-48

Hautmann S, Brander H, Lippolt HJ, Lorenz J (1999) K-Ar and (U + Th)-He chronometry of multistage alteration and mineralisation in the Hartkoppe rhyolite, Spessart, Germany. J Conf Abstr 4:769

Hoewe J, Sibbald T (1978) On the genesis of rabbit lake and other unconformity-type uranium in Northern Saskatchewan, Canada. Econ Geol 73:1451-1473

Hofmann R, Schürenberg H (1979) Geochemische Untersuchungen gangförmiger Barytvorkommen in Deutschland. Monogr Ser Miner Depos 17:1-80

Jones HD, Kesler SE, Furman FC, Kyle JR (1996) Sulfur isotope geochemistry of southern Appalachian Mississippi Valley-type deposits. Econ Geol 91:355-367

Jowett EC (1986) Genesis of Kupferschiefer $\mathrm{Cu}-\mathrm{Ag}$ deposits by convective flow of Rotliegend brines during Triassic rifting. Econ Geol 81:1823-1837

Jowett EC, Pearce GW, Rydzewski A (1987) A mid-Triassic paleomagnetic age of the Kupferschiefer mineralization in Poland based on a revised apparent polar wander path for Europe and Russia. J Geophys Res 92:581-598

Jowett RC, Roth T, Rydzewski A, Oszczepalski S (1991a) Background $\delta 34 \mathrm{~S}$ values of Kupferschiefer sulfides in Poland - pyrite-marcasite nodules. Miner Depos 26:89-98

Jowett RC, Rye RO, Rydzewski A, Oszczepalski S (1991b) Isotopic evidence for the addition of sulfur during formation of the Kupferschiefer deposits in Poland. Zentralbl Geol Paläontol 1991:1001-1015

Kading KC (2005) The Zechstein in the stratigraphic scale of Germany 2002. Newsl Stratigr 41:123-127

Kampschulte A, Buhl D, Strauss H (1998) The sulfur and strontium isotopic compositions of Permian evaporites from the Zechstein basin, northern Germany. Geol Rundsch 87:192-199

Kister P, Vieillard P, Cuney M, Quirt D, Laverret E (2005) Thermodynamic constraints on the mineralogical and fluid composition evolution in a clastic sedimentary basin: the Athabasca Basin (Saskatchewan, Canada). Eur J Mineral 17:325-341

Koerner A, Kissling E, Miller SA (2004) A model of deep crustal fluid flow following the $\mathrm{Mw}=8.0$ Antofagasta, Chile, earthquake. J Geophys Res 109:B06307

Kotzer TG, Kyser TK (1995) Petrogenesis of the Proterozoic Athabasca Basin, northern Saskatchewan, Canada, and its relation to diagenesis, hydrothermal uranium mineralization and paleohydrogeology. Chem Geol 120:45-89

Kramm U, Wedepohl KH (1991) The isotopic composition of strontium and sulfur in seawater of late Permian (Zechstein) age. Chem Geol 90:253-262

Krouse HR, Parafinikus J, Nowak J, Halas S (2006) Millimeter scale variations in the isotopic composition of vein sulphide minerals in the Kupferschiefer deposits, Lubin area, SW Poland. Isot Environ Health Stud 42:327-333

Kucha H (1990) Geochemistry of the Kupferschiefer, Poland. Geol Rundsch 79:387-399

Lippolt HJ (1986) Nachweis altpaläozoischer Primäralter (Rb-Sr) und karbonischer Abkühlungsalter (K-Ar) der Muskovit-BiotiteGneise des Spessarts und der Biotit-Gneise des Böllsteiner Odenwaldes. Geol Rundsch 75:569-583

Lodemann M, Fritz P, Wolf M, Ivanovich M, Hansen BT, Nolte E (1997) On the origin of saline fluids in the KTB (continental deep drilling project of Germany). Appl Geochem 12:831-849

Lüders V, Möller P (1992) Fluid evolution and ore deposition in the Harz Mountains (Germany). Eur J Mineral 4:1053-1068

Lüders V, Gerler J, Hein UF, Reutel CJ (1993) Chemical and thermal development of ore-forming solutions in the Harz Mountains: a 
summary of fluid inclusion studies. Monogr Ser Miner Depos 30:117-132

Machel HG (2001) Bacterial and thermochemical sulfate reduction in diagenetic settings - old and new insights. Sediment Geol 140:143-175

Machel HG, Krouse HR, Sassen R (1995) Products and distinguishing criteria of bacterial and thermochemical sulfate reduction. Appl Geochem 10:373-389

Markl G, von Blanckenburg F, Wagner T (2006) Iron isotope fractionation during hydrothermal ore deposition and alteration. Geochim Cosmochim Acta 70:3011-3030

Marowsky G (1969) Schwefel-, Kohlenstoff- und SauerstoffIsotopenuntersuchungen am Kupferschiefer als Beitrag zur genetischen Deutung. Contrib Mineral Petrol 22:290-334

Menning M, Gast R, Hagdorn H, Kading KC, Szurlies M, Nitsch E (2005) Time scale for the Permian and Triassic groups in the stratigraphical scale of Germany 2002, cyclostratigraphic calibration of the Dyassic and Germanic Triassic groups and the age of the strata Roadium to Rhaetium 2005. Newsl Stratigr 41:173-210

Miller SA, Collettini C, Chiaraluce L, Cocco M, Barchi M, Kaus BJP (2004) Aftershocks driven by a high-pressure $\mathrm{CO}_{2}$ source at depth. Nature 427:724-727

Minissale A, Vaselli OK, Tassi F, Magro G, Grechi GP (2002) Fluid mixing in carbonate aquifers near Rapolano (central Italy): chemical and isotopic constraints. Appl Geochem 17:1329-1342

Möller P, Woith H, Dulski P, Luders V, Erzinger J, Kampf H, Pekdeger A, Hansen B, Lodemann M, Banks D (2005) Main and trace elements in KTB-VB fluid: composition and hints to its origin. Geofluids 5:28-41

Muchez P, Slobodnik M, Viaene W, Keppens E (1994) Mississippi Valley-type $\mathrm{Pb}-\mathrm{Zn}$ mineralization in eastern Belgium: indications for gravity-driven flow. Geology 22:1011-1014

Müller G, Nielsen H, Ricke W (1966) Schwefel-isotopen-verhältnisse in formationswässern und evaporiten nord- und süddeutschlands. Chem Geol 1:211-220

Muir-Wood R, King GCP (1993) Hydrological signatures of earthquake-strain. J Geophys Res B 98:22035-22068

Murawski H (1954) Bau und Genese von Schwerspatlagerstätten des Spessart. Neues Jahrb Geol Paläontol Monatsh 1954:145163

Nasir S, Okrusch M, Kreuzer H, Lenz H, Höhndorf A (1991) Geochronology of the Spessart crystalline complex, Mid-German crystalline rise. Mineral Petrol 43:39-55

Nurmi PA, Kukkonen IT, Lahermo PW (1988) Geochemistry and origin of saline groundwaters in the Fennoscandian Shield. Appl Geochem 3:185-203

Ohmoto H, Lasaga AC (1982) Kinetics of reactions between aqueous sulfates and sulfides in hydrothermal systems. Geochim Cosmochim Acta 46:1727-1745

Ohmoto H, Goldhaber MB (1997) Sulfur and carbon isotopes. In: Barnes HL (ed) Geochemistry of hydrothermal ore deposits, 3rd edn. Wiley, New York, pp 435-486

Okrusch M, Weber K (1996) Der Kristallinkomplex des Vorspessart. Z Geol Wiss 24:141-174

Okrusch M, Lorenz JA, Weyer S (2007) The genesis of sulfide assemblages in the former Wilhelmine mine, Spessart, Bavaria, Germany. Can Mineral 45:723-750

Oliver NHS, McLellan JG, Hobbs BE, Cleverley JS, Ord A, Feltrin L (2006) Numerical models of extensional deformation, heat transfer, and fluid flow across basement-cover interfaces during basin-related mineralization. Econ Geol 101:1-31

Oszczepalski S (1999) Origin of the Kupferschiefer plymetallic mineralization in Poland. Miner Depos 34:599-613

Paul J (1985) Stratigraphie und Fazies des südwestdeutschen Zechsteins. Geol Jahrb Hess 113:59-73
Paul J (2006) Der Kupferschiefer: Lithologie, Stratigraphie, Fazies und Metallogenese eines Schwarzschiefers. Z Deutsch Ges Geowiss 157:57-76

Person M, Raffensperger JP, Ge SM, Garven G (1996) Basin-scale hydrogeologic modeling. Rev Geophys 34:61-87

Piestrzynski A, Pieczonka J, Gluszek A (2002) Redbed-type gold mineralisation, Kupferschiefer, south-west Poland. Miner Depos 37:512-528

Piestrzynski A, Wodzicki A (2000) Origin of the gold deposit in the Polkowice-West Mine, Lubin-Sieroszowice Mining District, Poland. Miner Depos 35:37-47

Pouchou JL, Pichoir F (1985) "PAP" procedure for improved quantitative microanalysis. Microbeam Anal 20:104-105

Rick B (1990) Sulfur and oxygen isotopic composition of Swiss Gipskeuper (Upper Triassic). Chem Geol 80:243-250

Sawlowicz Z (1989) On the origin of copper mineralization in the Kupferschiefer: a sulfur isotope study. Terra Nova 1:339-343

Sawlowicz Z (1990) Primary copper sulphides from the Kupferschiefer, Poland. Miner Depos 25:262-271

Sawlowicz Z, Wedepohl KH (1992) The origin of rhytmic sulfide bands from the Permian sandstones (Weissliegendes) in the footwall of the Fore-Sudetic Kupferschiefer (Poland). Miner Depos 27:242-248

Schmid H, Weinelt W (1978) Lagerstätten in Bayern. Geol Bavarica $77: 1-160$

Schmidt FP, Friedrich GH (1988) Geologic setting and genesis of Kupferschiefer mineralization in West Germany. In: Friedrich GH, Herzig PM (eds) Base metal sulfide deposits in volcanic and sedimentary environments. SGA Spec Publ No. 6, SpringerVerlag, Berlin, pp 25-59

Schmidt FP, Schumacher C, Spieth V, Friedrich G (1986) Results of recent exploration for copper-silver deposits in the Kupferschiefer of West Germany. In: Friedrich GH et al (eds) Geology and metallogeny of copper deposits. SGA Spec Publ No. 4, SpringerVerlag, pp 572-582

Schmidt-Mumm A, Wolfgramm M (2002) Diagenesis and fluid mobilisation during the evolution of the North German Basinevidence from fluid inclusion and sulphur isotope analysis. Mar Petrol Geol 19:229-246

Schmidt-Mumm A, Wolfgramm M (2004) Fluid systems and mineralization in the north German and Polish basin. Geofluids $4: 315-328$

Schmitt RT (2001) Zur Petrographie, Geochemie und Buntmetallmineralisation des Zechstein-1 (Werra-Folge) im Gebiet Huckelheim Großkahl (Nordwestlicher Spessart). Mitt Naturwiss Museum Stadt Aschaffenburg 20:1-100

Schumacher C, Kaidies E, Schmidt FP (1984) Der basale Zechstein der Spessart-Rhön-Schwelle. Z Deutsch Geol Ges 135:563-571

Schwinn G, Wagner T, Markl G, Baatartsogt B (2006) Quantification of mixing processes in ore-forming hydrothermal systems by combination of stable isotope and fluid inclusion analyses. Geochim Cosmochim Acta 70:965-982

Seward TM, Barnes HL (1997) Metal transport by hydrothermal ore fluids. In: Barnes HL (ed) Geochemistry of hydrothermal ore deposits, 3rd edn. Wiley, New York, pp 435-486

Shock EL, Sassani DC, Willis M, Sverjensky DA (1997) Inorganic species in geologic fluids: correlations among standard molal thermodynamic properties of aqueous ions and hydroxide complexes. Geochim Cosmochim Acta 61:907-950

Sibson RH (2000) Fluid involvement in normal faulting. J Geodyn 29:469-499

Speczik S (1995) The Kupferschiefer mineralization of central Europe: new aspects and major areas of future research. Ore Geol Rev 9:411-426

Staude S, Wagner T, Markl G (2007) Mineralogy, mineral chemistry and fluid evolution of the hydrothermal Wenzel deposit, southern 
Germany: implications for the formation of Kongsberg-type silver deposits. Can Mineral 45:1147-1176

Stober I, Bucher K (1999a) Deep groundwater in the crystalline basement of the Black Forest region. Appl Geochem 14:237-254

Stober I, Bucher K (1999b) Origin of salinity of deep groundwater in crystalline rocks. Terra Nova 11:181-185

Stober I, Bucher K (2004) Fluid sinks within the earth's crust. Geofluids 4:143-151

Stober I, Bucher K (2005) The upper continental crust, an aquifer and its fluid: hydaulic and chemical data from $4 \mathrm{~km}$ depth in fractured crystalline basement rocks at the KTB test site. Geofluids 5:8-19

Stober I, Bucher K (2007) Hydraulic properties of the crystalline basement. Hydrogeol J 15:213-224

Sverjensky DA, Shock EL, Helgeson HC (1997) Prediction of the thermodynamic properties of aqueous metal complexes to 1000 degrees $\mathrm{C}$ and $5 \mathrm{~kb}$. Geochim Cosmochim Acta 61:1359-1412

van Wees JD, Stephenson RA, Ziegler PA, Bayer U, McCann T, Dadlez R, Gaupp R, Narkiewicz M, Bitzer F, Scheck M (2000) On the origin of the Southern Permian Basin, Central Europe. Mar Petrol Geol 17:43-59

Vaughan DJ, Sweeny M, Friedrich G, Diedel R, Hanczyk C (1989) The Kupferschiefer: an overview with an appraisal of the different types of mineralization. Econ Geol 84:1003-1027

Wagner T, Lorenz J (2002) Mineralogy of complex Co-Ni-Bi vein mineralization Bieber deposit, Spessart, Germany. Mineral Mag $66: 385-407$
Warren JK (2000) Evaporites, brines and base metals: low-temperature ore emplacement controlled by evaporite diagenesis. Aust J Earth Sci 47:179-208

Wedepohl KH, Rentsch J (2006) The composition of brines in the early diagenetic mineralization of the Permian Kupferschiefer in Germany. Contrib Mineral Petrol 152:323-333

Weyer S, Schwieters J (2003) High precision Fe isotope measurements with high mass resolution MC-ICPMS. Int J Mass Spectrom 226:355-368

Wilkinson JJ, Jenkin GRT, Fallick AE, Foster RP (1995) Oxygen and hydrogen isotopic evolution of the Variscan crustal fluids, south Cornwall, U.K. Chem Geol 123:239-254

Wilson AM, Boles JR, Garven G (2000) Calcium mass transport and sandstone diagenesis during compaction-driven flow: Stevens Sandstone, San Joaquin basin, California. Geol Soc Amer Bull 112:845-856

Wood SA, Samson IM (1998) Solubility of ore minerals and complexation of ore metals in hydrothermal solutions. Rev Econ Geol 10:33-76

Zheng YF, Hoefs J (1993) Stable isotope geochemistry of hydrothermal mineralizations in the Harz Mountains. II. Sulfur and oxygen isotopes of sulfides and sulfate and constraints on metallogenetic models). Monogr Ser Miner Depos 30:211-229

Ziegler PA (1987) Geodynamic model for Alpine intra-plate compressional deformation in western and central Europe. Geol Soc Lond Spec Publ 44:63-85 